\title{
Who is Talking about Whom? Determinants and Consequences
}

\author{
Gerald Ward \\ University of Maryland
}

\begin{abstract}
August 2020
Despite the importance of peer firm information in capital markets, we know little about what peer firms say about each other in financial disclosures. This paper provides evidence on this topic and documents that approximately 17 percent of earnings conference calls contain at least one peer firm mention from managers. I also find that managers are, on average, more likely to mention peer firms with superior performance. This tendency, however, is less pronounced around upward perception events. Finally, I provide evidence that capital market participants find peer firm mentions informative.
\end{abstract}




\section{Introduction}

People use information about peer firms to make a variety of decisions in capital markets. For example, managers observe peers to shape their financial and strategic decisions (e.g., Badertscher, Shroff, \& White, 2013; Francis, Hasan, Mani, \& Ye, 2016; Leary \& Roberts, 2014). Financial analysts, investment bankers, and equity investors employ peer valuation multiples to assist in their equity valuations of firms (e.g., Bhojraj \& Lee, 2002; De Franco, Hope, \& Larocque, 2015; Vismara, Signori, \& Paleari, 2015). And boards of directors use peers to determine the amount of compensation to pay their executives (e.g., Faulkender \& Yang, 2010; Gong, Li, \& Shin, 2011). Despite this importance of peer information, we know little about one aspect of it: what peer firms say about each other in financial disclosures.

In this paper, I provide preliminary evidence on this topic by examining peer mentions within earnings conference calls. In this setting, managers provide detail about their announced quarterly earnings and their prospects and in doing so may discuss peer firms. ${ }^{1}$ As an example, the management of Sprint in their fourth quarter of 2014 conference call stated the following about their peers:

I watch the acts of my competitors, and I find it amusing that T Mobile claims the fastest network, that AT\&T claims the strongest LTE signal or that Verizon claims the most reliable network making you think they have twice the coverage, this just further clouds the consumers perception of network experiences. (Seeking Alpha, 2015)

\footnotetext{
${ }^{1}$ I examine earnings conference calls rather than earnings announcements because there is often more industry related information in the former (e.g., Brochet, Kolev, \& Lerman, 2018).
} 
The above quote and others like it raise two broad questions which I explore in this paper. ${ }^{2}$ Are managers more likely to mention some types of peer firms over others? And are managers' comments about peer firms informative?

For the first question, I specifically examine whether managers are more likely to mention better or worse performing peer firms. To provide insight into this issue, I adapt a framework from social comparison theory. This framework provides competing motives as to why managers may compare themselves against better or worse performing peers (e.g., Gibbons \& Buunk, 1999; Helgeson \& Mickelson, 1995; Wood, 1989). On the one hand, the "self-improvement" motive predicts that managers are more likely to mention better performing peers (e.g., Collins, 1996, 2000; Wheeler, 1966); managers may minimize the differences between themselves and better performing peers in order to convey that they are or will soon be performing as well as these peers. On the other hand, the "self-enhancement" motive predicts that managers are more likely to mention worse performing peers (e.g., Wills, 1981); managers may highlight the differences between themselves and worse performing peers in order to present their own historical or expected performance in a favorable light. Given these competing motives, it is not clear ex-ante whether managers, on average, are more likely to mention better or worse performing peers.

As for the second research question, I specifically investigate whether managers' comments about peer firms elicit significant reactions from peer firm equity investors. While focal firm disclosures are often informative about peer firm prospects as established in the information transfer literature (e.g., Foster, 1981; Kim, Lacina, \& Park, 2008; Ramnath, 2002), it is not clear whether explicit mentions of peer firms contain any incremental information. While peer mentions may contain incremental information given the industry-expertise of focal firm

\footnotetext{
${ }^{2}$ See Appendix A for more example quotes.
} 
managers, they may also contain no information because the mentions are value-neutral in nature, contain stale news, or consist of cheap talk.

To answer the two research questions empirically, I gather a sample of 37,380 earnings conference calls from 2,859 firms over the period 2007 to 2018 . For each firm hosting a conference call for a specific quarter, I define their peer firms as those firms that are sufficiently similar to them using the Text-based Network Industry Classifications from Hoberg and Phillips (2010, 2016). I employ two approaches to identify peer firm mentions within a conference call: a keyword search approach using cleaned and shortened CRSP historical company names and a supervised machine learning technique called named entity recognition. After combining the two approaches, I document that at least one peer firm is first mentioned by management in 17 percent of earnings conference calls.

I next find that managers are, on average, more likely to mention better performing peer firms where performance is measured using a price-to-book ratio, a return on assets (ROA) ratio, or prior quarter stock returns. In terms of economic significance, a better performing peer is approximately three percentage points more likely to be mentioned than a worse performing peer - a figure that corresponds to an approximate six percent increase on the base probability of being mentioned. While these findings are consistent with the self-improvement motive, they are somewhat surprising given the conclusions of prior accounting papers - namely that managers often present their own performance in a favorable light by choosing low performance benchmarks (e.g., Cassar, 2001; Lewellen, Park, \& Ro, 1996; Schrand \& Walther, 2000).

Therefore, I check the robustness of my findings. First, the findings hold if I re-run the analysis on a subsample of peer mentions in which the peer firm is first mentioned by management in the management discussion section (as opposed to either section) of the 
conference call; this robustness test alleviates the concern that managers only mention better performing peers because they are prompted by analysts to do so. Second, the findings would be less surprising if they are driven by managers discussing the better performance of noncompetitor peer firms (i.e., pure customers, partners, and suppliers); managers could explain that such strong performance benefits them too. The results in a competitor mention subsample are, however, similar to not only the main findings but those in a non-competitor mention subsample, providing evidence against this alternative explanation. Third, managers may merely mention the most visible peer firms who also happen to be strong performers (i.e., peer firm visibility may be an omitted correlated variable). After further controlling for peer firm visibility, however, the results again show a tendency towards mentioning better performing peers.

As an additional analysis, I examine whether managers continue to favor the mentioning of better performing peer firms around upward perception events. Around such events, managers may be more tempted to present their own performance in a favorable light by comparing themselves with worse performing peer firms. The results only somewhat support this idea though: managers still have a dominant - but less pronounced - tendency towards mentioning better performing peers in times of upward perception.

To answer the second research question, I investigate whether peer firm equity investors react to peer firm mentions by management. Using two-day absolute cumulative abnormal returns around focal firms' earnings conference calls, I document that peer mentions in general elicit significant reactions from peer firm investors. I also find that mentions involving worse performing peers evoke larger stock price reactions than no mentions and those mentions involving better performing peers. As for economic significance, a mention (worse peer performance mention) on average changes the market capitalization of the average peer firm by 13 (31) million U.S. dollars. These results are robust to the employment of an alternative control 
sample that addresses the concern that the group of mentioned peer firms may have had larger absolute cumulative abnormal returns even in the absence of being mentioned. I also show that the results are unlikely to be caused by analysts initiating the release of information and are unlikely to be due to differences in stock return correlations (with focal firms) for mentioned and unmentioned peers firms.

The above results contribute to the disclosure literature by analyzing a new form of disclosure, namely "peer disclosure". Prior literature has largely focused on "self disclosure" disclosing information about your own performance and prospects - rather than "peer disclosure" - disclosing information about the performance and prospects of other firms. ${ }^{3}$ In this study, I provide initial evidence on peer disclosure by documenting which types of peer firms are most likely to be mentioned and by showing that peer disclosure is a useful source of information for capital market participants. ${ }^{4}$ These contributions complement those of Cao, Fang, and Lei (2019) who focus on a different aspect of peer disclosure: firms using social media to disseminate bad news about their peer firms.

As mentioned above, my findings contrast those of prior accounting papers on performance benchmarks. Prior studies show that managers bias their performance benchmarks downwards rather than upwards - whether it be choosing a worse performing peer group when disclosing relative share price performance (e.g., Cassar, 2001; Lewellen et al., 1996) or choosing the lowest prior-period earnings number when announcing current earnings (e.g., Schrand \&

\footnotetext{
${ }^{3}$ For literature reviews on self disclosure, see Healy and Palepu (2001) and Beyer, Cohen, Lys, and Walther (2010).

${ }^{4}$ In one table, Jennings, Lee, and Matsumoto (2017) also analyze peer mentions in earnings conference calls, but their focus is different from mine. They find that managers and analysts are more likely to mention peer firms that are geographically close to the focal firm; the explanation being that managers are more knowledgeable about other firms in the same geographic area and that analysts prefer nearby firms to reduce their costs of gathering and analyzing information.
} 
Walther, 2000). I bring the "self-improvement" motive to the accounting literature and show that managers in an earnings conference call setting appear to favor better performing peer benchmarks, a preference which is supported in non-business research settings (e.g., Collins, 1996; Gerber, Wheeler, \& Suls, 2018). The direction of comparison is important because upwards comparisons (i.e., performance-aspiration gaps) motivate managerial learning and affect firm policies as shown in the performance feedback theory literature (e.g., Cyert \& March, 1963; Greve \& Gaba, 2017).

I also contribute to the information transfer literature. Several papers have empirically examined information transfer in capital markets. For example, researchers have focused on the information transfers from earnings announcements and conference calls (e.g., Brochet et al., 2018; Foster, 1981; Ramnath, 2002), management earnings forecasts (e.g., Baginski, 1987; Han, Wild, \& Ramesh, 1989; Pyo \& Lustgarten, 1990; Kim et al., 2008), or other disclosure events (see Hope and Zhao (2018) for an overview). While these studies conclude that investors of peer firms react to material information released by focal firms, it is less clear whether peer mentions contain incremental information. ${ }^{5}$ This paper suggests that management's comments about peer firms are a useful source of information for peer firm investors.

The rest of the paper is structured as follows. In the next section, I discuss the related literature and state my two research questions. Section 3 describes the construction of the peer mentions database, while section 4 describes the research design and presents the results. In section 5 , I provide concluding remarks.

\footnotetext{
${ }^{5}$ Brochet et al. (2018) also find that peer mentions in earnings conference calls affect peer firm stock prices. Their analysis, however, is only a small part of their paper which focuses on the different sizes of the information transfers of earnings announcements versus earnings conference calls.
} 


\section{$2 \quad$ Literature and Research Questions}

\subsection{Are Managers More Likely to Mention Better or Worse Performing Peers?}

Social comparison theory provides a useful framework for thinking about the types of peers people compare themselves against. The theory originates from social psychology research and identifies two relevant motives for making up-down comparisons with others: "selfenhancement" and "self-improvement", which lead to downward and upward comparisons respectively (e.g., Gibbons \& Buunk, 1999; Helgeson \& Mickelson, 1995; Wood, 1989).

\subsection{A The Self-Enhancement Motive and Downward Comparisons}

If the self-enhancement motive dominates, people are predicted to compare themselves with worse performing peers. Wills (1981) argues that these comparisons are most likely when self-esteem is threatened. However, in my setting, there may be another reason why such comparisons occur. Managers may strategically mention worse performing peers to report their own firm performance in a favorable light.

Such strategic use of performance benchmarks has been found in other disclosure settings. For example, Lewellen et al. (1996) analyze the choice of industry and broader market indices chosen by management to compare their own stock performance against in corporate proxy statements; and find that both indices are biased downwards so that managements' own relative performance is overstated. Cassar (2001) reports similar findings using Australian (instead of U.S.) firms. Focusing instead on the strategic use of earnings number benchmarks in earnings announcements, Schrand and Walther (2000) find that managers choose the lowest prior-period comparative number to highlight the most favorable change in earnings. If similar strategic behavior also dominates in my setting, then I would expect managers to systematically compare themselves to worse performing peers. 


\subsection{B The Self-Improvement Motive and Upward Comparisons}

The comparer, however, may care the most about the self-improvement motive. In this case, the subject compares their own performance with that of a peer who outperforms them, elevating the comparer's self-esteem by making them believe that they are in the same category as the superior peer and motivating them to perform better in order to assimilate to the superior peer (e.g., Collins, 1996, 2000; Wheeler, 1966).

To make these ideas more concrete, Collins (1996) asks the reader to imagine a researcher with 10 publications comparing herself to a peer with 12 publications (holding constant the quality of the publications). Under the self-improvement motive, the researcher with 10 publications likely minimizes the significance of the two extra publications and places herself in the same ability group as the higher-achieving peer. The researcher's self-assessment is therefore enhanced because through this comparison she has changed her self-evaluation from someone with 10 publications to someone with " 10 or 12 " publications. The researcher may also realize that publishing two more publications is attainable given that a similar peer has already done so.

In experimental and field studies outside of business contexts, there is support for the self-improvement motive (i.e., upwards comparisons) dominating the self-enhancement motive (i.e., downwards comparisons). For example, in their meta analysis of such studies, Gerber et al. (2018) conclude:

In upward-downward choice studies, upward comparisons were preferred in laboratory settings and were depressed only modestly when threat was present. Field settings were associated with less clearly defined preferences although downward choices never predominated... The addition of a lateral choice to the 
experimental paradigm reduced the differences between choice preferences although upward selections still had the "edge". (p.6)

If the self-improvement motive also dominates in my setting, then I would expect managers, on average, to compare themselves to better performing peers. Managers may minimize differences between themselves and better performing peers to convince themselves and outside stakeholders that they are or will soon be performing as well as these peers. For example, managers may state that they are making similar investments as those peers who are performing well; or that they deserve a similar valuation as those peer firms with higher valuations.

Given the competing motives of self-enhancement and self-improvement and the mixed empirical evidence across sections $2.1 \mathrm{~A}$ and $2.1 \mathrm{~B}$, I state the below research question in open form:

Research Question 1: Are managers, on average, more likely to mention better or worse performing peer firms in their earnings conference calls?

\subsection{Are Peer Firm Mentions by Management Informative about Peer Firm Prospects?}

The idea that focal firm disclosures are often informative about peer firm prospects is well established in the information transfer literature. In fact, the information transfer literature around earnings announcements goes back at least four decades to Firth (1976) and Foster (1981). The basic premise of information transfer research is that firms have performancerelated factors in common, e.g., product market conditions, industry economic shocks, production-technology advancements, government regulation changes, and so on. Therefore, when investors observe how these common factors affect the focal firm, they can extrapolate this effect to peer firms which in turn affects peer stock prices. 
Several papers have empirically examined information transfer in capital markets. For example, some papers focus on the information transfers from earnings announcements and conference calls (e.g., Brochet et al., 2018; Foster, 1981; Ramnath, 2002), while others focus on the transfers from management earnings forecasts (e.g., Baginski, 1987; Han et al., 1989; Kim et al., 2008; Koo, Wu, \& Yeung, 2017; Pyo \& Lustgarten, 1990) and various other disclosure events (e.g., see Hope and Zhao (2018) for an overview). These studies conclude that investors of peer firms are likely to react to material information released by focal firms.

It is not clear, however, whether there is material information associated with peer firm mentions. On the one hand, peer mentions may contain new information about peer prospects and hence lead to abnormal changes in peer stock prices. This production of new information seems plausible given the industry-expertise of focal firm managers - for example, Hutton, Lee, and Shu (2012) conclude that managers have comparable industry knowledge to that of analysts. On the other hand, peer mentions may contain no new information because the mentions are value-neutral in nature, contain stale news, or consist of cheap talk. In this case, peer investors will not react to peer mentions. Given these competing reasons, I state my second research question in open form:

Research Question 2: Do peer firm mentions by management, on average, elicit significant reactions from peer firm investors? 


\section{Database of Peer Firm Mentions}

\subsection{Earnings Conference Call Transcripts}

I receive a sample of conference call transcripts from Seeking Alpha. ${ }^{6}$ The coverage across companies is broad with Seeking Alpha stating on their website that the "depth and breadth of our content is unmatched, with $8,600+$ tickers covered and 8,000 articles and earnings transcripts published every month" (Seeking Alpha, n.d.). The time period is also broad - any transcripts published on Seeking Alpha's website between January 2007 and April 2018. ${ }^{7}$ The format of a transcript usually consists of a header section, a management discussion section, and a Q\&A section. In the header section, Seeking Alpha often provides information about the conference call - the company's name and ticker as at the conference call date, the date of the conference call, the fiscal quarter and year of the earnings period, and often the participants on the call (namely the company executive names and their job titles, and the names of the financial analysts and their firms).

The initial sample from Seeking Alpha consists of 157,927 transcripts. Upon inspection of this sample, however, it is clear that some of these transcripts should be dropped. First, I drop any transcripts in which I cannot partition the conference call into its three sections. I also require that the management discussion section and the Q\&A section contain a meaningful

6 These transcripts can be found at https://seekingalpha.com/earnings/earnings-calltranscripts?sector=all. After signing a non-disclosure agreement, Seeking Alpha kindly provided all of their transcripts (published on or before 12/21/2018) for no charge.

7 The initial sample also includes transcripts from 2004, 2005, and 2006 but the coverage in these years is limited. So, transcripts from these years get dropped in latter analyzes. Also, the data on identifying peer firms (discussed in the next section) only provides data up to the end of 2017 , so some conference call transcripts from later on in 2018 are also dropped from the analysis. 
amount of text; ${ }^{8}$ a small amount of text likely signals that the conference call has only been partially transcribed. If I cannot extract fiscal quarter information from the header section, then I also drop the transcript - the rationale being that such transcripts are usually not related to earnings announcements but to other events such as one-off announcements or industry conferences. Finally, I remove duplicate transcripts and those that cannot be reliably merged with the Compustat and CRSP databases. These steps leave a sample of 104,608 transcripts (over 6,053 unique firms) that are available to be merged with the peer data, which is discussed next.

\subsection{A Set of Peers}

To identify a set of peers for each focal firm at a specific quarter period, I use the Text-based Network Industry Classifications (TNIC) from Hoberg and Phillips (2010, 2016). ${ }^{9}$ The definition and advantages of this classification are summarized on Hoberg and Phillips' website:

These new industry classifications are based on firm pairwise similarity scores from text analysis of firm $10 \mathrm{~K}$ product descriptions. Competitors are firm centric with each firm having its own distinct set of competitors - analogous to networks or a "Facebook" circle of friends. These new industry classifications are updated annually and offer more research flexibility, and are also more informative, than FIC (fixed industry) classifications such as SIC, NAICS, and the 10-K based FIC classifications. (Hoberg \& Phillips, 2016a)

\footnotetext{
${ }^{8}$ Specifically, I drop the management discussion (Q\&A) section if it contains less than 500 (250) words. I remove the copyright disclaimers at the bottom of the transcript before counting the words or running any other analysis.

9 The Text-based Network Industry Classifications are available from http://hobergphillips.tuck.dartmouth.edu/industryclass.htm.
} 
I choose the baseline TNIC dataset that is recommended for most research projects and is calculated to be as granular as three-digit Standard Industry Classification (SIC) codes. In this dataset, the mean (median) number of peers per focal firm-year is 374 (412), which is too many for the purposes of this study. So to reduce the number of peers, I make two restrictions: the similarity score between focal and peer firms must be equal to or higher than 0.0582 (the median score in the full dataset); and the maximum number of peers a focal firm can have is 30 (i.e., if after the first restriction there are still more than 30 peer firms, then the 30 with the highest similarity scores are kept). This latter number is guided by De Franco et al. (2015) who find that the $99^{\text {th }}$ percentile of the number of peers mentioned in an analyst report is 30 .

I remove any observations where either the focal or peer firm is in the financial industry (two-digit SIC codes between 60 and 67). The rationale for removal is threefold: financial firms often have different performance measures which would complicate identifying superior and inferior performing peers; investment banks and brokerage firms are often mentioned in the Q\&A section of the transcript in reference to the analysts employer which would lead to many false positive mentions; and financial firms often have long names that are hard to distinguish from one another complicating the identification of which peer is mentioned.

Finally, as $10-\mathrm{Ks}$ are annual disclosures by firms, the TNIC dataset is provided at an annual frequency. To be consistent with the quarterly frequency of conference calls, I transform the annual TNIC data to quarterly TNIC data by assuming that a focal firm's set of peers is constant throughout the focal firm's fiscal year. The resulting database of peers is then linked with historical company names which is discussed next. 


\subsection{Peer Mentions}

To identify peer mentions within earnings conference call transcripts, I begin with historical company names from CRSP. These names are cleaned in several steps so that their form resembles that of names mentioned in conference calls. I first remove gaps between any two single letter words (e.g., " A M S HEALTH SCIENCES INC" becomes "AMS HEALTH SCIENCES INC"). I then remove the word "THE" if it is the first word of the company name. I also expand common and unambiguous abbreviations sometimes used by CRSP to shorten long names (e.g., "TECHS" becomes "TECHNOLOGIES", "SVCS" becomes "SERVICES", etc.). From the end of company names, I remove common legal suffixes (e.g., "CORP", "LTD", "INC", etc.), state abbreviations (e.g., "DEL", "NV", "OH", etc.), single characters, and numerals (e.g., "I", "II", “III", etc.). As an example of the former step, "AMS HEALTH SCIENCES INC" becomes "AMS HEALTH SCIENCES". ${ }^{10}$

These cleaned names are then shortened using an algorithm; the basic premise behind the algorithm is the less common (or more unique) the start of a company name is, the shorter the name the algorithm outputs (see Appendix B for details). This algorithm aims to strike a balance between shortening company names enough to minimize false negative mentions but not so much as to increase false positive mentions (e.g., for "DELTA AIR LINES", the algorithm gives "DELTA AIR" rather than "DELTA"). Specifically, the algorithm outputs two names for each cleaned CRSP company name: (a) a short version name that has a smaller chance of false negatives but a higher chance of false positives; and (b) a long version name that is still often

\footnotetext{
${ }^{10}$ To double-check the validity of the cleaned CRSP company names, I compare them against another list of CRSP names that are independently hand-checked in another project (thank you to Musa Subasi for sharing this list). After hand-checking any discrepancies between the lists, I changed 253 names from my original cleaned CRSP names to those provided by the other prokect. I also modified 21 more company names that had typos or had other more familiar short names (e.g., "AMAZON.COM" becomes "AMAZON").
} 
shorter than the cleaned CRSP names and has a higher chance of false negatives and a lower chance of false positives. As an example, the short and long versions of "AMS HEALTH SCIENCES" are "AMS" and "AMS HEALTH" respectively. ${ }^{11}$

Using these short and long versions of peer company names, I identify peer company mentions with two approaches. The first approach searches through the transcript looking for an exact match to the short or long version of the names. To count as a mention, the peer name in the transcript has to be proper case (e.g., "Apple" rather than "apple" or "APPLE") or upper case if the original historical CRSP name starts with two or more single letter words (e.g., if the original name is "A M S HEALTH SCIENCES INC", then the short name version is "AMS" rather than "Ams"). This approach works well provided the name keyword assumptions hold. For example, false negatives are possible when the case assumption is wrong (e.g., "eBay" would be missed) or the length of the short or long name versions is too long. Another downside of this approach is that some names such as "ADAM INC", "BEST INC", "NEW YORK \& CO INC" with short and long versions of "Adam", "Best", and "New York" will likely lead to false positives. ${ }^{12}$

To get around these downsides, I employ a supervised machine learning technique called named entity recognition (NER) which classifies named entities in text into pre-defined categories like "individuals", "companies", "places", etc. I use the NER model from spaCy, which has been pre-trained on the OntoNotes 5 corpus - this corpus contains text from telephone

\footnotetext{
${ }^{11}$ If two or more peers from the same set of peers have the same short or long version names, I expand their short or long names slightly so that the peers could be distinguished from one another. When this is not possible or involves large name expansions (and hence likely false negative mentions), then these peers are dropped from the sample. When the focal and peer firms have the same short or long version names, then the focal-peer obervation is also dropped from the sample.

${ }^{12}$ For five peer names, I notice a high incidence of false positives so increase the length of the short or long name.
} 
conversations, newswire, newsgroups, broadcast news, broadcast conversation, and weblogs. ${ }^{13}$ After running the NER model on the conference call transcripts, I get a list of potential company names and an associated count of the number of times the name occurs. Upon inspection of these lists, I realize that the model is picking up many names which are not company names - a downside of using NER models is that they are sensitive to the training data set which, in this case, is not earnings conference call transcripts. Cleaning these lists involves removing the common incorrect names (e.g., "Board of Directors", "Securities and Exchange Commission", "General Counsel", etc.), common business abbreviations (e.g., "EPS", "GAAP", "Q2", etc.), other upper case words that do not match any cleaned CRSP historical names, focal firm tickers and names, and analyst firm names. The resulting cleaned name and count list is then fuzzy matched to the short or long version names.

Next I combine the search and NER approaches to form a final count of peer firm mentions. The final count variables take the maximum count from the two approaches with the exception that for problematic names, such as "ADAM INC", "BEST INC" and "NEW YORK \& CO INC", it equals the NER count. The primary variable I use in this paper is PEER_MENTION ${ }_{i, j, t}$, which equals one if peer firm $j$ has a positive mention count (either by its short or long name versions) in focal firm i's conference call at quarter $t$ and is first mentioned by focal firm managers (as opposed to by analysts), and zero if peer firm $j$ is not mentioned by managers or analysts. I require that managers first mention the peer so that it is their decision to do so, rather than management responding to an analyst who mentions the peer.

To determine the accuracy of PEER_MENTION $N_{i, j, t}$, I manually read 50 random focalpeer observations where PEER_MENTION $N_{i, j, t}$ equals one, and 50 random observations where

\footnotetext{
${ }^{13}$ spaCy is free to use and available from https://spacy.io/usage/linguistic-features. For more details about the OntoNotes 5 corpus, see https://catalog.Idc.upenn.edu/LDC2013T19.
} 
PEER_MENTION $N_{i, j, t}$ equals zero. Out of the 100 observations, hand-checking reveals that PEER_MENTION $N_{i, j, t}$ should equal one 45 times and zero 55 times. The proportion of actual positives that are correctly identified as such (i.e., the sensitivity of my measure) is 1.00, whereas the proportion of actual negatives that are correctly identified as such (i.e., the specificity of my measure) is approximately $0.91 .{ }^{14}$ The overall proportion of correctly classified mentions is 0.95 .

\subsection{Descriptive Statistics of Peer Mentions}

The final dataset that combines the conference call data, the set of peers data, and the peer mention data contains 521,636 focal-quarter-peer observations, 37,380 focal-quarter observations, and 2,859 $(3,768)$ unique focal (peer) firms. The average focal firm hosts a mean (median) of 13 (11) conference calls (or quarters) in the sample.

At the focal-quarter-peer level, the PEER_MENTION $N_{i, j, t}$ variable equals one 7,824 times or in other words a given peer in a given conference call is first mentioned by management 1.5 percent of the time. At the focal-quarter level, at least one peer firm is first mentioned by management in 6,401 conference calls (or 17.1 percent of the time). Sometimes more than one peer is mentioned in a conference call: two peers are mentioned in 953 conferences calls ( 2.6 percent of the time) and greater than two peers 212 times ( 0.6 percent of the time). Overall, 1,374 unique focal firms (48 percent of all focal firms) mention 1,195 unique peer firms (32 percent of all peer firms).

\footnotetext{
${ }^{14}$ Another limitation of the PEER_MENTION $N_{i, j, t}$ variable is that it does not capture peer company names that are referenced by their product (e.g., if "iPhone" but not "Apple" is mentioned then PEER_MENTION $N_{i, j, t}$ would equal zero for the peer firm "Apple"). Thus, the sensitivity score of 1.00 is overstated.
} 
Figure 1 below shows how the mentioning of peer firms varies across focal firms. In this figure, the sample of focal firms is restricted to only those firms that mention at least one peer firm in the sample period ( 48 percent of all focal firms). Panel A shows that just under half of these focal firms only mention one unique peer firm in the sample period, 22 percent mention two unique peers, 12 percent mention three unique peers, and the remaining 17 percent mention four or more unique peers. In Panel $B$, I show that just under half of the mentioning focal firms mention a peer in only one or two of their conference calls. A further 29 percent of the mentioning focal firms mention peers in three to six conference calls and the remaining 22 percent mention peers in more than six conference calls.

If I use the proportion (rather than the number) of conference calls that contain peer mentions and further restrict the sample to those focal firms that have four or more conference calls in the sample period, there is a similar mentioning pattern (not shown in Figure 1). Around 52 percent of these focal firms mention peers in 20 or less percent of their conference calls; a further 32 percent of these focal firms mention peers in more than 20 and up to and including 50 percent of their conference calls; and the remaining focal firms mention peers in more than 50 percent of their conference calls.

Insert Figure 1 Here

To provide more detail on the characteristics of focal firms mentioning peer firms, I present bivariate statistics on those focal-quarters whose conference calls contain peer mentions versus those that do not. These statistics are exploratory in nature and as a result I use some of the analogous variables to those used in section 4.1's analysis plus two other variables: (a) the number of peers for each focal-quarter, and (b) whether the focal firm is announcing a 
non-negative earnings surprise or not (as measured against the mean consensus analysts' forecast). It is also worth noting that there is likely some noise in the classification of focalquarters into those with and without peer mentions because the group of peers used in this paper could differ from that used by managers.

The bivariate statistics are shown in Table 1. Compared to those focal-quarters without peer mentions, those with peer mentions on average have higher price-to-book ratios, ROA ratios, and stock returns measured over $(-93,-3)$ where 0 is the focal firm's conference call date. These differences suggest that focal firms are, on average, more likely to mention peers when they are performing well. It is worth noting, however, that non-negative earnings surprises occur slightly more often in those focal-quarters without peer mentions. Table 1 also documents that those focal-quarters with peer mentions involve, on average, larger focal firms, focal firms with more peer firms, and focal firms whose peer firms have closer matches in business operations (as measured by the TNIC similarity score averaged across the focal-quarter's peer firms). Finally, Table 1 reports that focal firms that report after (as opposed to before) the majority of their peers are, on average, more likely to mention a peer firm but the difference in proportions is not large nor statistically significant.

Figure 2 below shows how the mentioning of peer firms varies across peer firms. In this figure, the sample of peer firms is restricted to only those firms that are mentioned at least once by managers in the sample period ( $32 \%$ of all peer firms). Panel $A$ shows that just over half of these peer firms are only mentioned by one focal firm in the sample period, 19 percent are mentioned by two focal firms, 10 percent are mentioned by three focal firms, and the remaining 
18 percent are mentioned by four or more focal firms. In Panel B, I show that just under half of the mentioned peer firms get mentioned in only one or two focal firm conference calls. A further 26 percent of the mentioned peer firms get mentioned in three to six conference calls and the remaining 26 percent get mentioned in more than six conference calls.

Insert Figure 2 Here

\section{$4 \quad$ Research Design and Results}

\subsection{Are Managers More Likely to Mention Better or Worse Performing Peers?}

\subsection{A Main Finding}

To examine whether managers, on average, are more likely to mention better or worse performing peer firms, I estimate the following logistic regression:

$$
\begin{aligned}
& \text { PROB(PEER_MENTION } \left.{ }_{i, j, t}=1\right) \\
& \quad=\psi\left(\alpha_{0}+\alpha_{1} \text { PEER_BETTER_PER } F_{i, j, t}+\Sigma \beta_{m} \text { CONTROLS }_{i, j, t}+\varepsilon_{i, j, t}\right)
\end{aligned}
$$

In equation (1), PEER_MENTION $N_{i, j, t}$ is an indicator variable that equals one if peer $j$ is first mentioned by management in focal firm i's conference call in quarter $t$, and 0 if peer $j$ is not mentioned by management or analysts in the conference call.

Given that the relative proportion of mentioned versus unmentioned peers is highly imbalanced in my sample, the estimated coefficients from logistic regressions could be significantly biased and inefficient (Owen, 2007). To alleviate this concern, I follow the commonly used under-sampling method to randomly remove unselected peer observations when estimating logistic regressions (e.g., Chawla, Japkowicz, \& Kolcz, 2003). Specifically, for each mentioned peer firm, I randomly select another peer firm from the same focal firm's TNIC 
peer set that is not mentioned by management or analysts in the conference call (e.g., if focal firm $i$ in quarter $t$ mentions two peer firms then I randomly pick two unmentioned peer firms from firm i's quarter $t^{\prime}$ s set of peers). This approach of forming a control group is used in other peer selection research (e.g., De Franco et al., 2015; Gong et al., 2011).

The variable $P E E R_{-} B E T T E R_{-} P E R F_{i, j, t}$ is set equal to one if peer firm $j$ 's performance minus focal firm i's performance at quarter $t$ is non-negative, and zero otherwise. Performance is either measured as the price-to-book ratio, ROA, or stock return measured over $(-93,-3)$ where 0 is the focal firm's conference call date. The price-to-book ratio and ROA variables are measured at the end of the focal firm's fiscal quarter for the focal firm and at the end of the peer firm's fiscal quarter for the peer firm, where the chosen peer fiscal quarter is the most recent quarter that focal firm management could observe at the time of the focal firm's conference call. ${ }^{15}$

The vector of variables CONTROLS $S_{i, j, t}$ contains several variables. First, I control for relative firm size calculated as the $\log$ (peer firm assets) minus $\log$ (focal firm assets). ${ }^{16}$ The rationale for controlling for relative firm size is that, all else equal, managers are more likely to mention larger peer firms because they are likely more economically relevant to them. Second, I add the TNIC similarity score which captures the similarity in $10-\mathrm{K}$ product descriptions; the

\footnotetext{
${ }^{15}$ The three relative performance dummy variables - PEER_BETTER_P2 $B_{i, j, t}$, PEER_BETTER_ROA $A_{i, j, t}$ , and PEER_BETTER_RET $T_{i, j, t}$ - equal one for mentioned (unmentioned) peers 52 (47), 55 (45), and 52 (49) percent of the time respectively. As for the size of the comparisons, the mean of peer firm j's performance minus focal firm i's performance at quarter $t$ (winsorized at the 5 percent level) for the mentioned (unmentioned) peer subsamples is $0.010(-0.299), 0.011(-0.035)$, and $0.011(-0.002)$ for the three respective performance measures.

${ }^{16}$ I choose assets (rather than sales or market capitalization) to measure size difference because assets is less directly related to recent performance. For example, differences in market capitalizations may capture recent stock price performance differences which is an independent variable of interest.
} 
higher the score the more similar the business operations between the focal and peer firms, and hence the more likely the peer firm will be mentioned. I also control for whether the peer has already reported its quarterly earnings (variable equals one) or not (variable equals zero) because focal firms may be more likely to comment on a peer that has recently announced their results. I run the regression with calendar quarter-year fixed effects, cluster the standard errors by focal firm, and winsorize all continuous variables at the 1 and 99 percentiles.

Panel A of Table 2 presents the descriptive statistics of the above variables. The mean values of the PEER_BETTER_PERF $F_{i, j, t}$ variables show that there is a near even balance between peer firms performing better and worse than focal firms in the regression sample. As for the control variables, focal firms are, on average, bigger than their peer firms. Finally, the correlations (untabulated) among the independent variables are not large (maximum 0.30) which suggests that multicollinearity is not a problem.

$* * * * * * * * * * * * * * * * * * * * * * * * * * * * *$ Insert Table 2 Here $* * * * * * * * * * * * * * * * * * * * * * * * * * * * * * *$

Table 3 presents the estimates from regression equation (1). In Panel A, the sample consists of peer firm mentions in which the peer firm is first mentioned by management in either section of the conference call. The coefficients on the performance difference variables are all positive suggesting that managers are more likely to mention those peers with superior performance. To get a sense of the economic significance of these effects, I present average discrete changes in square brackets; an average discrete change is the change in probability of mentioning a peer if a continuous (indicator) independent variable changes by one standard deviation (one unit). ${ }^{17}$ Averaging across the three performance measures, a better performing

\footnotetext{
${ }^{17}$ Average discrete changes are calculated using the methods of Long and Freese (2014).
} 
peer is approximately three percentage points more likely to be mentioned than a worse performing peer - a figure that corresponds to an approximate six percent increase on the base probability of being mentioned.

As for the control variables in Panel A, larger peer firms and those with closer business operations with the focal firm are much more likely to be mentioned which is as expected. Managers are more likely to mention those peers that have reported their quarterly earnings but the effect is not statistically significant. And the goodness of fit for the logit models is around 64 and 65 percent for the sensitivity and specificity measures respectively.

$* * * * * * * * * * * * * * * * * * * * * * * * * * * * * \quad$ Insert Table 3 Here

While the above relative performance findings are consistent with the self-improvement motive from the social comparison theory literature (e.g., Collins, 1996; Gerber et al., 2018), the findings are somewhat surprising given the conclusions of prior accounting papers - namely that managers often present their performance in a favorable light by choosing low performance benchmarks (e.g., Cassar, 2001; Lewellen et al., 1996; Schrand \& Walther, 2000). Therefore, in the next section I examine the robustness of my findings.

\subsection{B Additional Analyses and Robustness Issues}

One possible concern with the above findings is that managers are only mentioning better performing peers because they are prompted by analysts to do so. It is worth reemphasizing, however, that the above results only use peer mentions in which management mentions the peer firm before analysts do. Nevertheless, analysts may still initiate the peer mention without explicitly saying the peer firm's name (e.g., analysts may mention "iPhone" rather than "Apple"). To address this concern, I re-estimate regression equation (1) using only 
those peer mentions in which the peer firm is first mentioned by management in the discussion section of the conference call (i.e., the section before analysts have an opportunity to speak in the conference call). The results are shown in Panel B of Table 3 and are similar to those in Panel A except that the coefficient on PEER_BETTER_ROA $A_{i, j, t}$ is no longer statistically significant at conventional levels.

Another way analysts may indirectly prompt peer mentions is by revealing their questions to managers before the conference call begins - a practice that is documented by Brown, Call, Clement, and Sharp (2019). Managers may want to get in front of these questions to control the message and while doing so mention peer firms. While I cannot completely rule out this alternative explanation, I can provide evidence against it by re-running regression equation (1) with an additional control variable: the number of analysts that cover both the focal and peer firms divided by the number of analysts that cover the focal firm (where both the numerator and denominator are measured during the respective conference call's fiscal year). The higher this analyst overlap variable the more likely a revealed question relates to the respective peer firm. With this extra control variable, however, the results (untabulated) are similar to those reported in Table 3.

Another potential issue with the results in Table 3 is that the randomly chosen control group consists of, by chance, atypically poorly performing firms. So as a robustness test, I reestimate the regressions in Table 3 with two new sets of randomly chosen unmentioned peers and find similar results to those reported in Table 3. It is also possible that the mentioning of the same peer firm by different focal firms may not represent independent observations. So as another robustness test, I cluster the standard errors by peer (instead of focal) firm and find that although the PEER_BETTER_ROA $A_{i, j, t}$ coefficients lose their statistical significance the results remain the same as those reported in Table 3. 
The results in Table 3 would be less surprising if they are driven by managers discussing the better performance of non-competitor peer firms (i.e., pure customers, partners, and suppliers); managers could explain that such strong performance benefits them too. To provide evidence against this alternative explanation, I check whether the results of Table 3 hold for both competitor and non-competitor peer mention subsamples. ${ }^{18}$ In Panel A of Table 4, I restrict the sample of peer mentions to those in which the peer is classified as a competitor and reestimate the regressions in Panel A of Table 3. The results show that a better performing competitor is approximately 4.4 percentage points more likely to be mentioned than a worse performing peer.

In Panel B of Table 4, I restrict the sample of peer mentions to those in which the peer is classified as a non-competitor and re-estimate the regressions in Panel A of Table 3. In this instance, all three performance difference coefficients are positive but the ROA one is statistically insignificant now. Using the methods of Long and Freese (2014), I compare the sizes of the average discrete changes between Panels $A$ and $B$ of Table 4 and find that while the latter are smaller in size they not statistically different from the former. Overall, the results in Table 4 do not support the alternative explanation that the results in Table 3 are driven by managers only discussing the better performance of non-competitor peer firms. ${ }^{19}$

Insert Table 4 Here

\footnotetext{
${ }^{18}$ Please see Appendix D for the classification of competitor and non-competitor peers. Also note that for the competitor (non-competitor) subsample one random control observation is selected such that it is not a non-competitor (competitor).

${ }^{19}$ The same conclusion is reached if I re-estimate the regressions of Panel $B$ in Table 3 using the competitor and non-competitor mention subsamples.
} 
Another alternative explanation for the findings in Table 3 is that managers are merely mentioning the most visible peer firms who also happen to be strong performers (i.e., peer firm visibility may be positively correlated with being mentioned and having strong performance and hence may be an omitted correlated variable). While I already control at least somewhat for peer firm visibility through $S I Z E_{-} D I F F_{i, j, t}$, I add a further control variable - an index of peer firm visibility - to regression equation (1). This visibility index variable is based on a peer firm's average rank within its peer group across three measures: (a) the number of analysts following the peer firm in the fiscal year of the focal firm's conference call; (b) the number of institutional investors holding the peer firm's shares at the calendar quarter end preceding the focal firm's conference call; and (c) the average monthly share turnover of the peer firm's stock in the fiscal quarter associated with the focal firm's conference call. ${ }^{20,21}$ With the inclusion of this peer firm visibility index variable, the results (untabulated) are similar to those reported in Table 3 and hence provide evidence against this omitted correlated variable explanation.

I next examine whether managers continue to favor the mentioning of better performing peer firms around upward perception events. Around such events, managers may be more tempted to present their own performance in a favorable light by comparing themselves

\footnotetext{
${ }^{20}$ The three measures are chosen based on prior literature (e.g., Bushee \& Miller, 2012; Drake, Jennings, Roulstone, \& Thornock, 2017) and on the requirement that they are not directly based on firm size or performance (given that these variables are already included in the regression).

${ }^{21}$ To illustrate how the index is calculated, I use the following example. Suppose that focal firm $i$ at quarter $t$ has ten peer firms and that peer firm $j$ has the fourth, third, and second highest metrics for the three respective measures (a) through (c). Then the visibility index for peer firm $j$ at quarter $t$ is calculated as $[(6 / 10)+(7 / 10)+(8 / 10)] / 3=0.7$ (i.e., an average across the three measures of the rank divided by the number of peers). It is worth noting that similar results are obtained for this robustness test if I do not average over the three ranks but rather include them as three separate control variables; or if I use $\log ($ num_analyst_following_peer +1$), \log ($ num_institutions_holding_peer +1$)$, and measure (c) as three separate control variables.
} 
with worse performing peer firms. To investigate this idea, I re-estimate equation (1) on upward and non-upward perception subsamples. The upward perception subsample covers those periods in which prior research has shown that managers try and manage investor perceptions upwards (e.g., Degeorge, Patel, \& Zeckhauser, 1999; Erickson \& Wang, 1999; Huang, Teoh, \& Zhang, 2013; Teoh, Welch, \& Wong, 1998). Following Huang et al. (2013), I define a focal firm as being in an upward perception period if any of the following conditions hold: (a) the focal firm's earnings announcement just meets or beats the mean consensus analyst forecast (i.e., the focal firm's consensus analyst forecast error is non-negative and less than 0.01); (b) the periods surrounding large stock issuance by the focal firm (i.e., the focal firm's current or future financial year has a level of stock issuance (sstk) divided by total assets that is greater than 0.1); and (c) the periods surrounding large M\&A by the focal firm (i.e., the focal firm's current or future financial year has a level of M\&A activity (aqc) divided by total assets that is greater than 0.1$)^{22}$ Focal periods that meet none of these conditions are defined as non-upward perception periods.

Table 5 summarizes the results of re-estimating the regressions of Panel A in Table 3 for the upward (Panel A) and non-upward perception (Panel B) period subsamples. For the upward perception period subsample, the PEER_BETTER_P2B $B_{i, j, t}$ and PEER_BETTER_RET $T_{i, j, t}$ coefficients are positive and statistically significant at the five percent level, whereas the PEER_BETTER_ROA $A_{i, j, t}$ coefficient is negative and insignificant. Using the methods of Long and Freese (2014), I compare the size of the average discrete changes between Panels A and B of Table 5 and find that while the former are smaller in size they are only statistically different

\footnotetext{
${ }^{22}$ Huang et al. (2013) also examine periods leading up to earnings restatements. I do not consider this setting though as there is no easily available data (in my sample period) that distinguishes between manipulation (the relevant ones) and innocuous restatements.
} 
for the PEER_BETTER_ROA $A_{i, j, t}$ variable. Overall, these results suggest that managers still have a dominant - but less pronounced - tendency towards mentioning better performing peers in times of upward perception. ${ }^{23}$

Insert Table 5 Here

As a comparison to the analysis in Table 5, I also examine those peer mentions that are first mentioned by analysts (rather than managers) for the upward and non-upward perception period subsamples. To the extent that the results in Table 5 are driven by managers' incentives and to the extent that analysts' incentives differ from those of managers, I would not expect the same pattern of results for managers and analysts. The results for analysts are shown in Table 6 and on first inspection the average discrete changes for the three performance difference variables are larger in the upward (Panel A) than the non-upward (Panel B) subsample. Using the methods of Long and Freese (2014), I formally compare the differences in average discrete changes and find that the PEER_BETTER_ROA $A_{i, j, t}$ change is statistically different in the upward than the non-upward subsample. Overall, these results paint the opposite pattern to those seen for managers and provide support for the explanation that managers' incentives are driving the results in Table 5.

\footnotetext{
${ }^{23}$ I find similar results if I re-estimate the regressions of Panel B in Table 3 using the upward and nonupward perception period subsamples; or if I individually examine the three upward perception events: just meet or beat earnings announcements, large stock issuances, or large M\&A.
} 


\subsection{Are Peer Mentions by Management Informative to Peer Firm Equity Investors?}

\subsection{A Main Finding}

In this section, I shift my focus from the relative performance determinant of peer mentions to an important consequence of them: the informativeness of peer mentions by management to peer firm equity investors. To examine this issue, I estimate the following ordinary least squares regression:

$$
A B S_{-} P E E R_{-} C A R 2_{i, j, t}=\alpha_{0}+\alpha_{1} M E N T I O N_{-} V A R S_{i, j, t}+\Sigma \beta_{m} C O N T R O L S_{i, j, t}+\varepsilon_{i, j, t}
$$

Equation (2) is estimated over the same sample as that used in section 4.1 with the following exceptions. If the mentioned peer firm hosts an earnings conference call within three calendar days either side of the focal firm's earnings conference call, then this peer mention observation and its associated control peer observation is dropped from the sample. If a control peer firm hosts an earnings conference call within three calendar days either side of the focal firm's earnings conference call, then this peer control observation is replaced with another peer control observation that does not host an earnings conference call within this window.

The dependent variable in equation (2) is peer firm j's absolute cumulative abnormal return measured over $(0,+1)$, where day 0 is the date of focal firm i's earnings conference call. The expected returns are calculated using the market model where beta is calculated over (-255, -3) and requires a minimum of 50 non-missing return days. The rationale for using absolute returns rather than signed ones is because the focal firms could be stating positive or negative information about the peer firm.

MENTION_VARS $S_{i, j, t}$ is one of four different peer mention variables. The first variable is the usual PEER_MENTION $N_{i, j, t}$ variable that equals one if peer firm $j$ is first mentioned by management in focal firm i's conference call in quarter $t$, and zero if peer firm $j$ is not mentioned by management or analysts in the conference call. The second variable, 
PEER_MENTION_COUNT $T_{i, j, t}$, is the number of times peer firm $j$ is mentioned by management in focal firm i's conference call in quarter $t$ with the caveat that to have a positive count the peer firm must be first mentioned by management. The third (fourth) variable, BETTER_MENTION $N_{i, j, t}\left(\right.$ WORSE_MENTION $\left.N_{i, j, t}\right)$, equals one if peer firm $j$ is better (worse) performing than focal firm $i$ at quarter $t$ and is first mentioned by management, and zero if either WORSE_MENTION $N_{i, j, t}\left(\right.$ BETTER_MENTION $\left._{i, j, t}\right)$ equals one or PEER_MENTION $N_{i, j, t}$ equals zero. Note that a better (worse) performing peer has at least two of the following variables equal to one (zero): PEER_BETTER_P2B $B_{i, j, t}, P E E R_{-} B E T T E R_{-} R E T_{i, j, t}$, and PEER_BETTER_ROA $A_{i, j, t} \cdot{ }^{24}$

The vector of variables CONTROLS $S_{i, j, t}$ contains several variables. First, I control for peer and focal firm size. I also control for peer and focal price-to-book ratios. The rationale for including these variables is that larger peers and those with higher price-to-book ratios are more likely to be mentioned, and firm size and market-to-book ratios are often correlated with abnormal returns (Fama \& French, 1993). I also use the TNIC similarity score which captures the similarity in 10-K product descriptions; the higher the score the more similar the businesses and hence the more expected information transfer between the two firms. Third, I use the absolute size of the focal firm's earnings surprise to control for the level of news contained in the focal firm's earnings announcement and conference call; the larger the news the greater the expected information transfer. I also control for whether the peer has reported before the focal firm or not because those that have may experience less information transfer (e.g., Ramnath, 2002; Thomas \& Zhang, 2008). Finally, I run the regression with calendar quarter-year fixed

\footnotetext{
${ }^{24}$ If I instead define better and worse performing peers using each performance measure separately, the results are qualitatively similar.
} 
effects, cluster the standard errors by conference call, and winsorize all continuous variables and PEER_MENTION_COUNT $T_{i, j, t}$ at the 1 and 99 percentiles.

Panel B of Table 2 presents the descriptive statistics of the above variables. The mean (median) of the dependent variable, $A B S_{-} P E E R_{-} C A R 2_{i, j, t}$, is approximately $2.3 \%(1.6 \%)$. The mean peer is mentioned approximately 1.4 times in a given conference call and of those peers that are mentioned the mean number increases to around 2.8 times (untabulated). The mean values of the BETTER_MENTION $N_{i, j, t}$ and WORSE_MENTION ${ }_{i, j, t}$ variables show that better performing peer mentions are more often in the sample than worse performing peer mentions but the difference is not too lop-sided. Finally, the correlations (untabulated) among the control variables are not large (maximum 0.37 ) which suggests that multicollinearity is not a problem.

Table 7 presents the estimates from regression equation (2). In Panel A, the sample consists of peer firm mentions in which the peer firm is first mentioned by management in either section of the conference call. In columns 1 and 2 , the coefficients on PEER_MENTION $N_{i, j, t}$ and PEER_MENTION_COUNT $T_{i, j, t}$ are positive and statistically significant at the ten and five percent levels respectively. The coefficients are reasonably small in magnitude however - a mentioned peer experiences approximately a 0.08 percentage point larger return which when multiplied by the mean peer firm's market capitalization equals approximately 13 million U.S. dollars. While these effects are not that economically large, they are consistent with managers, on average, making informative comments about peer firm prospects.

In column 3, I examine whether peer investors react more when the peer is better or worse performing than the focal firm. The results show that worse performing peer mentions are more informative than no mentions (with an economic magnitude of around 31 million U.S. dollars), whereas the difference for better performing peer mentions is not statistically 
significant. It is also worth noting that the coefficient on WORSE_MENTION $N_{i, j, t}$ is larger than the coefficient on BETTER_MENTION $N_{i, j, t}$ and the difference is statistically significant at the one percent level. One possible explanation for this finding is that managers from better performing firms are more informed (or make more credible comments) about the prospects of their peers firms.

\subsection{B Additional Analyses and Robustness Issues}

One possible concern with the above findings is that managers are only revealing information about peer firms because they are implicitly prompted by analysts to do so (i.e., in some sense analysts are the ones initiating the release of new information). While I cannot rule out this alternative explanation completely, I investigate whether the results in Panel A of Table 7 are similar to those for the subsample of peer mentions in which the peer firm is first mentioned by management in the discussion section of the conference call. The results of reestimating equation (2) on this alternative sample of peer mentions are displayed in Panel B of Table 7. The results in Panel B are similar to those displayed in Panel A except that the coefficients on PEER_MENTION $N_{i, j, t}$ and PEER_MENTION_COUNT $T_{i, j, t}$ are less precisely estimated. $^{25}$

\footnotetext{
${ }^{25}$ The results in Table 7 are also robust to the inclusion of an additional control variable: the scaled analyst overlap variable as described in section 4.1B. This variable may be important to the extent that analysts may indirectly initiate the release of information about peer firms by revealing their questions to managers before the conference call begins (as discussed in section 4.1B); and to the extent that more analyst overlap leads to more information transfer from focal firm to peer firm.
} 
Another potential issue with the analysis in Table 7 is that the group of mentioned peer firms may have had larger absolute cumulative abnormal returns even if they were not mentioned when compared with the randomly chosen control group of unmentioned peer firms. So as a robustness test, I re-estimate the regressions in Table 7 with two new sets of randomly chosen unmentioned peer firms and find similar results to those reported. I also use a different method to choose the unmentioned control sample - instead of randomly picking an unmentioned peer from the same set of peers for the given focal firm and quarter, I use the sample of unmentioned peer observations for the same focal firm and peer firm combination from different quarters. The advantage of this approach is that the mentioned and unmentioned groups are more likely to be similar across uncontrolled firm-specific dimensions that may affect the amount of information transfer (in the absence of a mention); but the disadvantage is that the mentioned and unmentioned peer firms are more likely exposed to different sets of information from different earnings conference calls.

Using this new control sample, I re-estimate the regressions in Table 7 but no longer control for calendar quarter-year fixed effects in order to keep the desired comparisons across quarters. The results are presented in Table 8 and are similar to those in Panels A and B of Table 7. Overall, these series of results provide evidence against the alternative explanation that the group of mentioned peer firms may have had larger absolute cumulative abnormal returns even in the absence of being mentioned.

Insert Table 8 Here

A related alternative explanation for the findings in Table 7 is that mentioned peers in general (rather than because of the mentions) have higher stock comovements with focal firms 
than unmentioned peers do. To provide evidence against this explanation, I re-run the regressions in Table 7 with an additional control variable: the Pearson correlation coefficient of focal firm and peer firm absolute daily returns over $(-93,-3)$ where day 0 is the focal firm's conference call date. The inclusion of this variable, however, leads to similar results (untabulated) as those presented in Table 7.

Finally, it is possible that observations involving the same peer firm are not independent in that the same investors are driving the abnormal returns. So as a final robustness test, I cluster the standard errors by peer firm (instead of conference call) and find similar results to those reported in Tables 7 and 8.

\section{Conclusion}

In this paper, I investigate what managers say about peer firms in earnings conference calls. Specifically, I ask whether managers are more likely to mention better or worse performing peer firms? And whether managers' comments about peer firms are informative? Using textual analysis and a supervised machine learning approach called named entity recognition, I first document that approximately 17 percent of earnings conference calls contain at least one peer firm mention by managers. Somewhat surprisingly, I find that managers are, on average, more likely to mention better performing peer firms. This tendency, however, is less

pronounced around upward perception events. Finally, this paper reveals that peer mentions elicit reactions from peer firm investors with mentions of worse performing peers drawing out the largest reactions.

These findings contribute to an emerging literature of peer disclosure in which managers discuss other firms. I provide initial evidence on peer disclosure by documenting 
which types of peer firms are most likely to be mentioned and by showing that peer disclosure is a useful source of information for capital market participants. Further work on peer disclosure could explore the context and content of peer mentions in more detail. For example, which other contexts and contents elicit the largest reactions from peer firm investors? 


\section{References}

Badertscher, B., Shroff, N., \& White, H. D. (2013). Externalities of public firm presence: Evidence from private firms' investment decisions. Journal of Financial Economics, 109(3), 682-706.

Baginski, S. P. 1987. Intraindustry information transfers associated with management forecasts of earnings. Journal of Accounting Research 25(2), 196-216.

Beyer, A., Cohen, D. A., Lys, T. Z., \& Walther, B. R. (2010). The financial reporting environment: Review of the recent literature. Journal of Accounting and Economics, 50(2-3), 296-343.

Bhojraj, S., \& Lee, C. M. (2002). Who is my peer? A valuation - based approach to the selection of comparable firms. Journal of Accounting Research, 40(2), 407-439.

Brochet, F., Kolev, K., \& Lerman, A. (2018). Information transfer and conference calls. Review of Accounting Studies, 23(3), 907-957.

Brown, L. D., Call, A. C., Clement, M. B., \& Sharp, N. Y. (2019). Managing the narrative: Investor relations officers and corporate disclosure. Journal of Accounting and Economics, 67(1), 58-79.

Bushee, B. J., \& Miller, G. S. (2012). Investor relations, firm visibility, and investor following. The Accounting Review, 87(3), 867-897.

Cao, S., Fang, V. W., \& Lei, L. G. (2019). Negative Peer Disclosure. Working Paper. Available from https://papers.ssrn.com/sol3/papers.cfm?abstract_id=3413317.

Cassar, G. (2001). Self-serving behaviour and the voluntary disclosure of capital market performance. Accounting Research Journal, 14(2), 126-137.

Chawla, N. V., N. Japkowicz, \& A. Kolcz. (2003). Learning from Imbalanced Data Sets. Proceedings of the ICML 2003 Workshop, Ottawa, Canada. 
Collins, R. L. (1996). For better or worse: The impact of upward social comparison on selfevaluations. Psychological Bulletin, 119(1), 51-69.

Collins, R. L. (2000). Among the better ones: Upward assimilation in social comparison. In J. Suls \& L. Wheeler (Eds.), Handbook of social comparison: Theory and research (pp. 141-158). New York, NY: Kluwer Academic / Plenum Press Publishers.

Cyert, R. M., \& March, J. G. (1963). A behavioral theory of the firm. Englewood Cliffs, NJ:Prentice-Hall.

De Franco, G., Hope, O. K., \& Larocque, S. (2015). Analysts' choice of peer companies. Review of Accounting Studies, 20(1), 82-109.

Degeorge, F., Patel, J., \& Zeckhauser, R. (1999). Earnings management to exceed thresholds. The Journal of Business, 72(1), 1-33.

Drake, M. S., Jennings, J., Roulstone, D. T., \& Thornock, J. R. (2017). The comovement of investor attention. Management Science, 63(9), 2847-2867.

Erickson, M., \& Wang, S. W. (1999). Earnings management by acquiring firms in stock for stock mergers. Journal of Accounting and Economics, 27(2), 149-176.

Fama, E. F., \& French, K. R. (1993). Common risk factors in the returns on stocks and bonds. Journal of Financial Economics, 33(1), 3-56.

Faulkender, M., \& Yang, J. (2010). Inside the black box: The role and composition of compensation peer groups. Journal of Financial Economics, 96(2), 257-270.

Firth, M. 1976. The impact of earnings announcements on the share price behavior of similar type firms. The Economic Journal 86(342), 296-306. 
Foster, G. 1981. Intra-industry information transfers associated with earnings releases. Journal of Accounting and Economics 3(3), 201-232.

Francis, B., Hasan, I., Mani, S., \& Ye, P. (2016). Relative peer quality and firm performance. Journal of Financial Economics, 122(1), 196-219.

Freeman, R. N. (1987). The association between accounting earnings and security returns for large and small firms. Journal of Accounting and Economics, 9(2), 195-228.

Gerber, J. P., Wheeler, L., \& Suls, J. (2018). A social comparison theory meta-analysis 60+ years on. Psychological Bulletin, 144(2), 177.

Gibbons, F. X. \& Buunk, B. P. (1999). Individual differences in social comparison: Development of a scale of social comparison orientation. Journal of Personality and Social Psychology, 76(1), 129-142.

Gofman, M., Segal, G., \& Wu, Y. (2018). Production networks and stock returns: The role of vertical creative destruction. Working Paper. Available from https://papers.ssrn.com/sol3/papers.cfm?abstract_id=2981447.

Gong, G., Li, L. Y., \& Shin, J. Y. (2011). Relative performance evaluation and related peer groups in executive compensation contracts. The Accounting Review, 86(3), 1007-1043.

Greve, H. R., \& Gaba, V. (2017). Performance feedback in organizations and groups: Common themes. The Oxford Handbook of Group and Organizational Learning.

Han, J. C., J. J. Wild, and K. Ramesh. 1989. Managers' earnings forecasts and intra-industry information transfers. Journal of Accounting and Economics 11(1), 3-33. 
Healy, P. M., \& Palepu, K. G. (2001). Information asymmetry, corporate disclosure, and the capital markets: A review of the empirical disclosure literature. Journal of Accounting and Economics, 31(1-3), 405-440.

Helgeson, V. S. \& Mickelson, K. D. (1995). Motives for social comparison. Personality and Social Psychology Bulletin, 21(11), 1200-1209.

Hoberg, G., \& Phillips, G. (2010). Product market synergies and competition in mergers and acquisitions: A text-based analysis. The Review of Financial Studies, 23(10), 3773-3811.

Hoberg, G., \& Phillips, G. (2016). Text-based network industries and endogenous product differentiation. Journal of Political Economy, 124(5), 1423-1465.

Hoberg, G., \& Phillips, G. (2016a, December 15). Retrieved from http://hobergphillips.tuck.dartmouth.edu/

Hope, O. K., \& Zhao, W. (2018). Market reactions to the closest peer firm's analyst revisions. Accounting and Business Research, 48(4), 345-372.

Huang, X., Teoh, S. H., \& Zhang, Y. (2013). Tone management. The Accounting Review, 89(3), 1083-1113.

Hutton, A. P., Lee, L. F., \& Shu, S. Z. (2012). Do managers always know better? The relative accuracy of management and analyst forecasts. Journal of Accounting Research, 50(5), 12171244.

Jennings, J., Lee, J., \& Matsumoto, D. A. (2017). The effect of industry co-location on analysts' information acquisition costs. The Accounting Review, 92(6), 103-127.

Kim, Y., M. Lacina, \& Park, M. S. (2008). Positive and negative information transfers from management forecasts. Journal of Accounting Research 46(4), 885-908. 
Koo, D. S., Julie Wu, J., \& Yeung, P. E. (2017). Earnings attribution and information transfers. Contemporary Accounting Research, 34(3), 1547-1579.

Leary, M. T., \& Roberts M. R. (2014). Do peer firms affect corporate financial policy? Journal of Finance, 69(1):139-178.

Lewellen, W. G., Park, T., \& Ro, B. T. (1996). Self-serving behavior in managers' discretionary information disclosure decisions. Journal of Accounting and Economics, 21(2), 227-251.

Long, J. S., \& Freese, J. (2014). Regression Models for Categorical Dependent Variables Using Stata, Third Edition. College Station, TX: Stata Press.

Owen, A. (2007). Infinitely imbalanced logistic regression. Journal of Machine Learning Research 8(4), 761-773.

Pyo, Y., \& Lustgarten S. (1990). Differential intra-industry information transfer associated with management earnings forecasts. Journal of Accounting and Economics 13(4), 365-379.

Ramnath, S. (2002). Investor and analyst reactions to earnings announcements of related firms: An empirical analysis. Journal of Accounting Research 40(5), 1351-1376.

Schrand, C. M., \& Walther, B. R. (2000). Strategic benchmarks in earnings announcements: The selective disclosure of prior-period earnings components. The Accounting Review, 75(2), 151177.

Seeking Alpha. (n.d.). Retrieved from https://seekingalpha.com/page/about_us

Seeking Alpha. (2014, October 24). Retrieved from https://seekingalpha.com/article/2592985ultratechs-utek-ceo-art-zafiropoulo-on-q3-2014-results-earnings-call-transcript?part=single.

Seeking Alpha. (2015, May 5). Retrieved from https://seekingalpha.com/article/3141626-sprints-q4-2014-results-earnings-call-transcript?part=single. 
Seeking Alpha. (2015a, June 29). Retrieved from https://seekingalpha.com/article/3292085cinedigms-cidm-ceo-chris-mcgurk-on-q4-2015-results-earnings-call-transcript.

Seeking Alpha. (2017, April 27). Retrieved from https://seekingalpha.com/article/4066519starbucks-sbux-q2-2017-results-earnings-call-transcript?part=single.

Seeking Alpha. (2017a, July 30). Retrieved from https://seekingalpha.com/article/4092460costar-groups-csgp-ceo-andy-florance-on-q2-2017-results-earnings-call-transcript.

Teoh, S. H., Welch, I., \& Wong, T. J. (1998). Earnings management and the underperformance of seasoned equity offerings. Journal of Financial Economics, 50(1), 63-99.

Thomas, J., \& Zhang, F. (2008). Overreaction to intra-industry information transfers? Journal of Accounting Research, 46(4), 909-940.

Vismara, S., Signori, A., \& Paleari, S. (2015). Changes in underwriters' selection of comparable firms pre-and post-IPO: same bank, same company, different peers. Journal of Corporate Finance, 34, 235-250.

Wheeler, L. (1966). Motivation as a determinant of upward comparison. Journal of Experimental Social Psychology, 1, 27-31.

Wills, T. A. (1981). Downward comparison principles in social psychology. Psychological Bulletin, 90, 245-271.

Wood, J. V. (1989). Theory and research concerning social comparisons of personal attributes. Psychological Bulletin, 106, 231-248. 


\section{Appendix A: Examples of Peer Mentions in Earnings Conference Call Transcripts}

Starbuck's management discussing their Q2 2017 results:

"First of all, there's no evidence whatsoever that any national company, even those companies that are discounting coffee significantly, with McDonald's nationally or Dunkin' Donuts in New England, what Panera is trying to do, there's no evidence whatsoever that we have, that there is anything that they are doing that is affecting us adversely. So I just want to get that off the table. The competitive issues question is just a nonevent for us." (Seeking Alpha, 2017)

Ultratech's management discussing their Q3 2014 results:

"I think it's a significant growth area for the company but our competition, specifically $K L A$ very strong company, with great technology and a great product. We think ours is a little bit better and a better cost of ownership." (Seeking Alpha, 2014)

Cinedigm's management discussing their Q4 2015 results:

"As you think about Cinedigm, we think it's fair to compare our growth plans to those of Lions Gate in their early small cap days. Like Cinedigm that company grew both organically and through M\&A activity, implementing an innovative and disruptive strategy and transformed itself into a tremendous industry success story." (Seeking Alpha, 2015a)

CoStar Group's management discussing the performance of their business Apartments.com in their Q2 2017 results:

"During the first half of '17, we've delivered twice as many leases as Apartment Guide, $5 x$ more leases than ForRent and $5 x$ more leases than Zillow. Apartments.com has taken a completely different approach than our competitors have." (Seeking Alpha, 2017a) 


\section{Appendix B: Algorithm for Shortening Company Names}

This algorithm takes in the cleaned CRSP historical company names and outputs shortened names to be used for identifying peer firm mentions in earnings conference call transcripts. Below is the list of the major types of input and output names used in the algorithm. ${ }^{26}$

\begin{tabular}{|c|c|}
\hline Jame & me \\
\hline $\begin{array}{l}\text { Cleaned name contains one word which is } \\
\text { "somewhat common"* } \\
\text { (e.g., "NIKE") }\end{array}$ & $\begin{array}{l}\text { Short version name: the one word (e.g., "NIKE") } \\
\text { Long version name: same as short version } \\
\text { Frequency: } 2.3 \text { percent of unique peer names }\end{array}$ \\
\hline $\begin{array}{l}\text { Cleaned name contains two or more words in } \\
\text { which the first word is "somewhat common" and } \\
\text { the second word is "not that common"** } \\
\text { (e.g., "EMERGE ENERGY SERVICES") }\end{array}$ & $\begin{array}{l}\text { Short version name: the first two words (e.g., } \\
\text { "EMERGE ENERGY") } \\
\text { Long version name: same as short version } \\
\text { Frequency: } 19.3 \text { percent of unique peer names }\end{array}$ \\
\hline $\begin{array}{l}\text { Cleaned name contains one or more words in } \\
\text { which the first word is "uncommon"*** } \\
\text { (e.g., "ORASURE TECHNOLOGIES") }\end{array}$ & $\begin{array}{l}\text { Short version name: the first word (e.g., } \\
\text { "ORASURE") } \\
\text { Long version name: the first word plus a second } \\
\text { word if available (e.g., "ORASURE TECHNOLOGIES") } \\
\text { Frequency: } 67.8 \text { percent of unique peer names }\end{array}$ \\
\hline $\begin{array}{l}\text { Cleaned name contains two or more words in } \\
\text { which the first word is "common"**** and the } \\
\text { second word is "somewhat common" } \\
\text { (e.g., "ADVANCED MICRO DEVICES") }\end{array}$ & $\begin{array}{l}\text { Short version name: the first two words (e.g., } \\
\text { "ADVANCED MICRO") } \\
\text { Long version name: the first two words plus a third } \\
\text { word if available (e.g., "ADVANCED MICRO } \\
\text { DEVICES") } \\
\text { Frequency: } 4.0 \text { percent of unique peer names }\end{array}$ \\
\hline $\begin{array}{l}\text { Cleaned name contains two or more words in } \\
\text { which the first word is "common" and the second } \\
\text { word is "uncommon" } \\
\text { (e.g., "BLUE DOLPHIN ENERGY") }\end{array}$ & $\begin{array}{l}\text { Short version name: the first two words (e.g., } \\
\text { "BLUE DOLPHIN") } \\
\text { Long version name: same as short version } \\
\text { Frequency: } 1.2 \text { percent of unique peer names }\end{array}$ \\
\hline
\end{tabular}

\footnotetext{
${ }^{26}$ I define major cases as consisting of at least 50 unique peer names. There are 11 non-major input and output types which are available upon request.
} 


\begin{tabular}{|l|l|}
\hline $\begin{array}{l}\text { Cleaned name contains two words in which the first } \\
\text { and second words are "common" }\end{array}$ & $\begin{array}{l}\text { Short version name: the first two words (e.g., } \\
\text { "AMERICAN SOFTWARE") }\end{array}$ \\
& $\begin{array}{l}\text { Long version name: same as short version } \\
\text { Frequency: 1.8 percent of unique peer names }\end{array}$ \\
\hline $\begin{array}{l}\text { Cleaned name contains three or more words in } \\
\text { which the first and second words are "common" } \\
\text { and third word is "very common"**** }\end{array}$ & $\begin{array}{l}\text { Short version name: the first three words plus the } \\
\text { fourth word if available (e.g., "CORPORATE } \\
\text { (e.g., "CORPORATE EXECUTIVE BOARD") }\end{array}$ \\
& $\begin{array}{l}\text { EXECUTIVE BOARD") } \\
\text { Frequency: } 1.7 \text { percent of unique peer names }\end{array}$ \\
\hline
\end{tabular}

Tables notes:

* A word is "somewhat common" when it is in the set that contains the union of the ten thousand most common English words list (https://github.com/first20hours/google-10000-english), the ten thousand most common $10-\mathrm{K}$ filing words list (https://sraf.nd.edu/textualanalysis/resources/\#Master\%20Dictionary), and the 100 most common business abbreviations list (taken selectively from https://en.wikipedia.org/wiki/List_of_business_and_finance_abbreviations) BUT NOT in the set that contains the corresponding union of the two one thousand most common word lists and the business abbreviations list.

** A word is "not that common" when it is NOT in the set that contains the union of the two one thousand most common word lists and the business abbreviations list.

*** A word is "uncommon" when it is NOT in the set that contains the union of the two ten thousand most common word lists and the business abbreviations list.

**** A word is "common" when it is in the set that contains the union of the two one thousand most common word lists and the business abbreviations list.

$* * * * *$ A word is "very common" when it is in the set that contains the union of the two two hundred most common word lists and the business abbreviations list. 


\section{Appendix C: Variable Definitions}

\begin{tabular}{|c|c|}
\hline Variable & Definition \\
\hline$A B S_{-} F O C A L_{-} E A_{-} S U R_{i, j, t}$ & $\begin{array}{l}\text { The absolute value of the earnings surprise of focal firm } i \text { at } \\
\text { quarter } t \text {. The earnings surprise is measured as the actual } \\
\text { earnings minus the most recent mean consensus analysts' } \\
\text { forecast preceding the earnings announcement all divided by } \\
\text { the fiscal quarter end stock price. }\end{array}$ \\
\hline$A B S_{-} P E E R_{-} C A R 2_{i, j, t}$ & $\begin{array}{l}\text { The absolute value of peer firm } j \text { 's cumulative abnormal return } \\
\text { measured over }(0,+1) \text {, where day } 0 \text { is the date of focal firm } i \text { 's } \\
\text { earnings conference call. The expected returns are calculated } \\
\text { using the market model where beta is calculated over }(-255,-3) \\
\text { and requires a minimum of } 50 \text { non-missing return days. }\end{array}$ \\
\hline BETTER_MENTION $N_{i, j, t}$ & $\begin{array}{l}\text { An indicator variable that equals one if a better performing } \\
\text { peer firm } j \text { is first mentioned by management in focal firm i's } \\
\text { conference call in quarter } t \text {, and zero if either } \\
W O R S E_{-} M E N T I O N_{i, j, t} \text { equals one or PEER_MENTION } N_{i, j, t} \\
\text { equals zero. A better performing peer firm has at least two of } \\
\text { the following variables equal to one: PEER_BETTER_P } 2 B_{i, j, t} \text {, } \\
P E E R_{-} B E T T E R_{-} R E T_{i, j, t} \text {, and PEER_BETTER_ROA } A_{i, j, t} \text {. }\end{array}$ \\
\hline$F O C A L_{-} N O N \_N E G_{-} S U R P_{i, t}$ & $\begin{array}{l}\text { Equal one if focal firm i's earnings surprise is non-negative, and } \\
\text { zero if the earnings surprise is negative. The earnings surprise is } \\
\text { measured as the actual earnings minus the most recent mean } \\
\text { consensus analysts' forecast preceding the earnings } \\
\text { announcement all divided by the fiscal quarter end stock price. }\end{array}$ \\
\hline $\begin{array}{c}F O C A L_{-} P 2 B_{i, j, t} \& \\
F O C A L_{-} P 2 B_{i, t}\end{array}$ & $\begin{array}{l}\text { Focal firm i's price-to-book ratio measured at the end of the } \\
\text { focal firm's fiscal quarter. Price-to book ratio is the market } \\
\text { capitalization divided by the book value of equity. }\end{array}$ \\
\hline$F O C A L_{-} R E P O R T S_{-} L A T E R_{i, t}$ & $\begin{array}{l}\text { An indicator variable that equals one if more than } 50 \text { percent } \\
\text { of focal firm i's peer firms report their quarterly earnings } \\
\text { before the focal firm reports, and zero otherwise. }\end{array}$ \\
\hline
\end{tabular}




\begin{tabular}{|c|c|}
\hline FOCAL_RET90 ${ }_{i, t}$ & $\begin{array}{l}\text { Focal firm i's stock return measured over }(-93,-3) \text { where day } 0 \\
\text { is the focal firm's conference call date. }\end{array}$ \\
\hline$F O C A L_{-} R O A_{i, t}$ & $\begin{array}{l}\text { Focal firm i's return on assets ratio measured at the end of the } \\
\text { focal firm's fiscal quarter. Return on assets ratio is the } \\
\text { annualized year-to-date income before extraordinary items } \\
\text { divided by the book value of assets. }\end{array}$ \\
\hline $\begin{array}{c}F O C A L_{-} S I Z E_{i, j, t} \& \\
\text { FOCAL_SIZE } E_{i, t}\end{array}$ & $\begin{array}{l}\text { Focal firm i's } \log \text { (book value of assets). The book value of assets } \\
\text { is measured at the end of the focal firm's fiscal quarter. }\end{array}$ \\
\hline$N U M_{-} P E E R S_{i, t}$ & $\begin{array}{l}\text { The number of peers that focal firm } i \text { has at quarter } t \text {. For the } \\
\text { selection of the set of peers see section 3.2. }\end{array}$ \\
\hline$P E E R \_B E T T E R \_P 2 B_{i, j, t}$ & $\begin{array}{l}\text { An indicator variable that equals one if peer firm j's price-to- } \\
\text { book ratio minus focal firm i's price-to-book ratio is non- } \\
\text { negative, and zero otherwise. The price-to book ratio is the } \\
\text { market capitalization divided by the book value of equity. The } \\
\text { ratios are measured at the end of the focal firm's fiscal quarter } \\
\text { for the focal firm and at the end of the peer firm's fiscal quarter } \\
\text { for the peer firm, where the chosen peer fiscal quarter is the } \\
\text { most recent quarter that the focal firm management could } \\
\text { observe at the time of the focal firm's conference call. }\end{array}$ \\
\hline PEER_BETTER_RET $T_{i, j, t}$ & $\begin{array}{l}\text { An indicator variable that equals one if peer firm } j \text { 's stock } \\
\text { return minus focal firm i's stock return is non-negative, and } \\
\text { zero otherwise. Stock returns are measured over }(-93,-3) \\
\text { where day } 0 \text { is the focal firm's conference call date. }\end{array}$ \\
\hline$P E E R_{-} B E T T E R_{-} R O A_{i, j, t}$ & $\begin{array}{l}\text { An indicator variable that equals one if peer firm j's return on } \\
\text { assets ratio minus focal firm i's return on assets ratio is non- } \\
\text { negative, and zero otherwise. The return on assets ratio is the } \\
\text { annualized year-to-date income before extraordinary items } \\
\text { divided by the book value of assets. The ratios are measured at } \\
\text { the end of the focal firm's fiscal quarter for the focal firm and } \\
\text { at the end of the peer firm's fiscal quarter for the peer firm, } \\
\text { where the chosen peer fiscal quarter is the most recent quarter }\end{array}$ \\
\hline
\end{tabular}




\begin{tabular}{|c|c|}
\hline & $\begin{array}{l}\text { that the focal firm management could observe at the time of } \\
\text { the focal firm's conference call. }\end{array}$ \\
\hline PEER_MENTION $N_{i, j, t}$ & $\begin{array}{l}\text { An indicator variable that equals one if peer firm } j \text { is first } \\
\text { mentioned by management in focal firm i's conference call in } \\
\text { quarter } t \text {, and } 0 \text { if peer firm } j \text { is not mentioned by management } \\
\text { or analysts in the conference call. }\end{array}$ \\
\hline PEER_MENTION_COUNT ${ }_{i, j, t}$ & $\begin{array}{l}\text { The number of times peer firm } j \text { is mentioned by management } \\
\text { in focal firm i's conference call in quarter } t \text {. To have a positive } \\
\text { count, the peer must be first mentioned by management. To } \\
\text { have a zero count, the peer must not be mentioned either by } \\
\text { management or analysts. }\end{array}$ \\
\hline$P E E R_{-} P 2 B_{i, j, t}$ & $\begin{array}{l}\text { Peer firm j's price-to-book ratio measured at the end of the } \\
\text { peer firm's fiscal quarter, where the chosen fiscal quarter is the } \\
\text { most recent quarter that the focal firm management could } \\
\text { observe at the time of the focal firm's conference call. The } \\
\text { price-to-book ratio is the market capitalization divided by the } \\
\text { book value of equity. }\end{array}$ \\
\hline$P E E R \_R E P O R T S_{-} F I R S T_{i, j, t}$ & $\begin{array}{l}\text { An indicator variable that equals one if peer firm } j \text { reported its } \\
\text { quarterly earnings before focal firm } i \text {, and zero otherwise. }\end{array}$ \\
\hline$P E E R \_S I Z E_{i, j, t}$ & $\begin{array}{l}\text { Peer firm j's } \log \text { (book value of assets) measured at the end of } \\
\text { the peer firm's fiscal quarter, where the chosen fiscal quarter is } \\
\text { the most recent quarter that the focal firm management could } \\
\text { observe at the time of the focal firm's conference call. }\end{array}$ \\
\hline$S I Z E_{-} D I F F_{i, j, t}$ & $\begin{array}{l}\text { Peer firm } j \text { 's } \log \text { (book value of assets) minus focal firm } i \text { 's } \\
\log \text { (book value of assets). The book value of assets are } \\
\text { measured at the end of the focal firm's fiscal quarter for the } \\
\text { focal firm and at the end of the peer firm's fiscal quarter for the } \\
\text { peer firm, where the chosen peer fiscal quarter is the most } \\
\text { recent quarter that the focal firm management could observe } \\
\text { at the time of the focal firm's conference call. }\end{array}$ \\
\hline$T N I C \_S C O R E_{i, j, t}$ & The score from Hoberg and Phillips $(2010,2016)$ who analyze \\
\hline
\end{tabular}




\begin{tabular}{|c|c|}
\hline & $\begin{array}{l}\text { firms' } 10-K \text { product descriptions and calculate a similarity score } \\
\text { based on these descriptions for pairs of firms each year. The } \\
\text { higher the score the more similar the businesses. }\end{array}$ \\
\hline$T N I C \_S C O R E_{-} A V_{i, t}$ & $\begin{array}{l}\text { The mean TNIC_SCORE } E_{i, j, t} \text { across focal firm i's peers at } \\
\text { quarter } t \text {. }\end{array}$ \\
\hline $\begin{array}{c}U P W A R D \_P E R I O D S_{i, t} \& \\
N O N_{-} U P W A R D \_P E R I O D S_{i, t}\end{array}$ & $\begin{array}{l}\text { I define a focal firm period as an upward perception period if } \\
\text { any of the following conditions hold: (a) the focal firm's } \\
\text { earnings announcement just meets or beats mean consensus } \\
\text { analyst forecasts (i.e., the focal firm's consensus analyst } \\
\text { forecast error is non-negative and less than } 0.01 \text { ); (b) the } \\
\text { periods surrounding large stock issuance by the focal firm (i.e., } \\
\text { the focal firm's current or future financial year has a level of } \\
\text { stock issuance (sstk) divided by total assets that is greater than } \\
0.1 \text { ); and (c) the periods surrounding large M\&A by the focal } \\
\text { firm (i.e., the focal firm's current or future financial year has a } \\
\text { level of M\&A activity (aqc) divided by total assets that is } \\
\text { greater than 0.1). } \\
\text { Focal firm periods that meet none of these conditions are } \\
\text { defined as non-upward perception periods. }\end{array}$ \\
\hline WORSE_MENTION $N_{i, j, t}$ & $\begin{array}{l}\text { An indicator variable that equals one if a worse performing } \\
\text { peer firm } j \text { is first mentioned by management in focal firm i's } \\
\text { conference call in quarter } t, \text { and zero if either } \\
\text { BETTER_MENTION } N_{i, j, t} \text { equals one or PEER_MENTION } N_{i, j, t} \\
\text { equals zero. A worse performing peer firm has at least two of } \\
\text { the following variables equal to zero: PEER_BETTER_P2B } B_{i, j, t} \text {, } \\
\text { PEER_BETTER_RET } T_{i, j, t} \text {, and PEER_BETTER_ROA } A_{i, j, t} \text {. }\end{array}$ \\
\hline
\end{tabular}




\section{Appendix D: Classifying Peer Firms into Competitors and Non-Competitors}

To classify peer firms into competitors and non-competitors, I use two existing sources:

1. FactSet's Revere Supply Chain Relationships dataset, which classifies focal-peer relationships into four major categories - competitors, customers, partners, and suppliers - and provides the start and end dates of these relationships. ${ }^{27}$ For more information on this dataset please refer to Gofman, Segal, and Wu (2018). I clean this dataset by keeping all relationships in which the FactSet Entity ID can be easily linked to Compustat's gvkey, by dropping all relationships which span zero days, by removing duplicate relationships, and by creating reciprocal relationships (e.g., if firm $X$ is a supplier of firm $\mathrm{Y}$, then firm $\mathrm{Y}$ is a customer of firm $\mathrm{X}$ ).

2. Disclosed customers from $10-\mathrm{K}$ filings up to October 2014 which is provided by JeanNoël Barrot on his website (http://mitmgmtfaculty.mit.edu/jnbarrot/data/). For this dataset, I create the reciprocal relationship and assume the relationship lasts for the fiscal year period of the $10-\mathrm{K}$.

These two existing sources provide relationship data for around $58 \%$ of peer mention observations (i.e., those observations where PEER_MENTION $N_{i, j, t}$ equals one). To classify more peer mention observations, I create my own categorization scheme using the following steps:

(i) For each earnings conference call transcript containing a peer firm $j$ mention by management, I create a text file that contains the paragraph surrounding each peer firm j mention. After excluding text files that are too short (under 20 words), likely contain a transcription error (i.e., the longest word in the text file is over 40 characters and thus

\footnotetext{
${ }^{27}$ More specifically, FactSet provides the dates in which one of their analysts first noticed a relationship in public disclosures (the start date) and last noticed a relationship (the end date). As the disclosures are often 10-K filings and FactSet's start date is based on the 10-K filing date, I subtract a year from FactSet's start date (i.e., I assume that the relationship is active throughout the $10-K^{\prime}$ s respective fiscal year).
} 
likely contains several words stuck together without spaces), and those that cannot be reliably extracted from the conference call (e.g., sometimes it is not possible to identify whether management or analysts are mentioning the peer in the Q\&A section), I have text files for $87 \%$ of peer mention observations.

(ii) I then create a competitor keyword list which contains "compete", "competing", "competition", "competitive", "competitor", and "rival"; and a non-competitor keyword list which contains "client", "contract", "distribution", "collaboration", "collaborator", "collaborative", "collaborate", "partnership", "affiliation", "alliance", "joint_venture", "jointly_owned", "supplier", and "supply_chain". ${ }^{28}$ The competitor keyword list is created by choosing some of the most common and relevant nouns and verbs that appear in a subset of the text files of peers already classified as competitors (and not customers, partners, or suppliers) by the FactSet classification. The non-competitor keyword list is created by choosing some of the most common and relevant nouns and verbs that appear in a subset of the text files of peers already classified as noncompetitors (customers, partners, or suppliers) by the FactSet and Barrot classification. These lists are supplemented by other obvious relevant keywords that do not appear near the top of these word-frequency lists.

(iii) For each peer mention text file, I count the number of words that are in the competitor and non-competitor keyword lists. I then define a peer as a "competitor_text" if its text file contains at least one word in the competitor keyword list; and a peer as a "non_competitor_text" if its text file contains at least two words in the non-competitor list (or is classified as a customer or supplier using the Barrot data) and zero words in the

\footnotetext{
${ }^{28}$ The word "customer" also commonly appears in competitor text files so is not included in the noncompetitor keyword list.
} 
competitor keyword list; and a peer as unknown classification if the peer remains unclassified.

(iv) I define the final competitor and non-competitor classifications as follows:

a. I first classify the peer mention observations with FactSet data: if FactSet defines the peer as a competitor then it is a competitor; if FactSet defines the peer as a customer, partner, and/or supplier but not also a competitor then it is a non-competitor.

b. I second classify the peer mention observations without FactSet data but with a text classification: if my text classification defines the peer as a "competitor_text" then it is a competitor; if my text classification defines the peer as a "non_competitor_text" then it is a non-competitor. ${ }^{29}$

(v) This classification scheme classifies 5,222 (or $67 \%$ of) peer mention observations (i.e., observations where PEER_MENTION $N_{i, j, t}$ equals one) as competitors or noncompetitors. Of the 5,222 classified observations, 2,922 (56\%) are competitors and $2,300(44 \%)$ are non-competitors.

\footnotetext{
${ }^{29}$ To get a sense of the accuracy of the text classification scheme, I treat the classifications in part a. as the truth and then check them against the "competitor_text" and "non_competitor_text" classifications. The sensitivity (specificity) for the "competitor_text" and "non_competitor_text" variables is $21 \%(92 \%)$ and $22 \%(90 \%)$ respectively. Thus even though the text classification scheme does not classify many peer mention observations into either group it does a good job of not incorrectly assigning peer mention observations.
} 


\section{Figures and Tables}

\section{Figure 1: Do Peer Firm Mentions Vary Across Focal Firms?}

This figure shows how peer firm mentions vary across focal firms. The sample of focal firms is restricted to only those firms that mention at least one peer firm in the sample period (48 percent of all focal firms). Note that peer firms must be first mentioned by management.

\section{Panel A: The Number of Unique Peer Firms Mentioned}

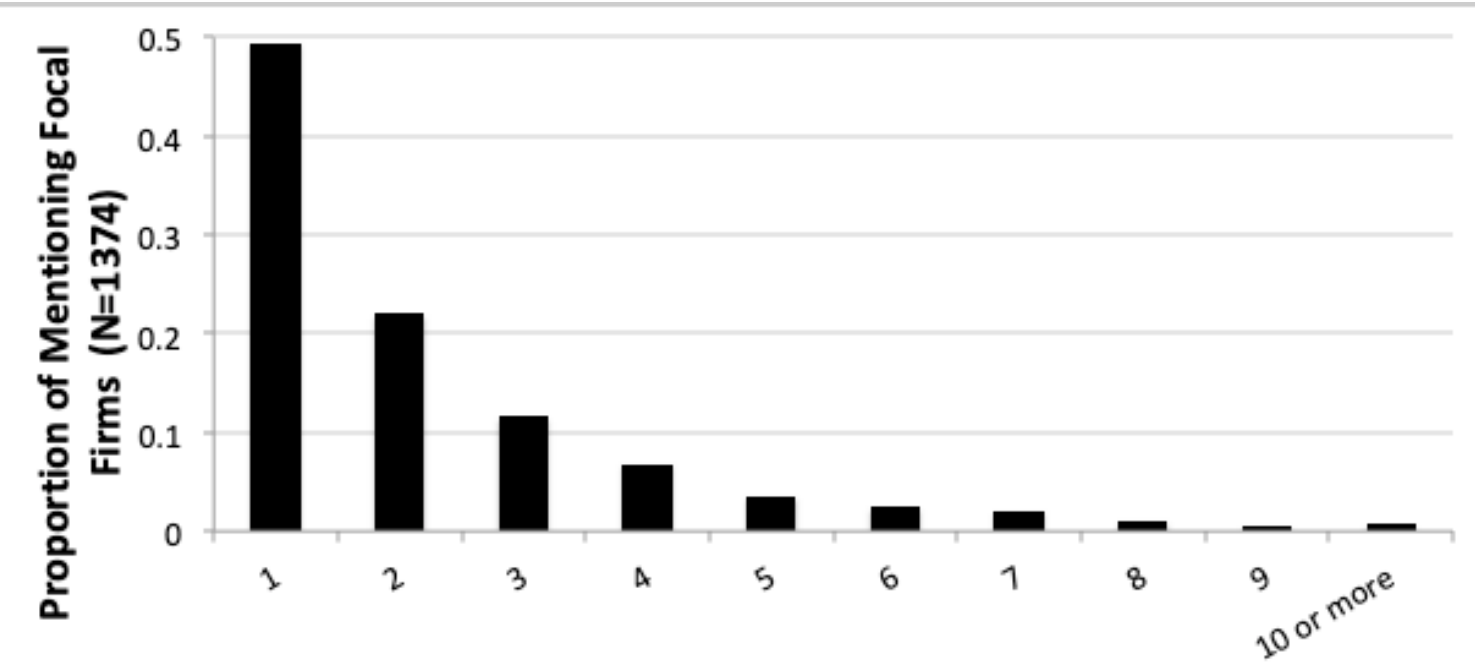

Number of Unique Peer Firms Mentioned

Panel B: The Number of Conference Calls with at Least One Peer Firm Mention

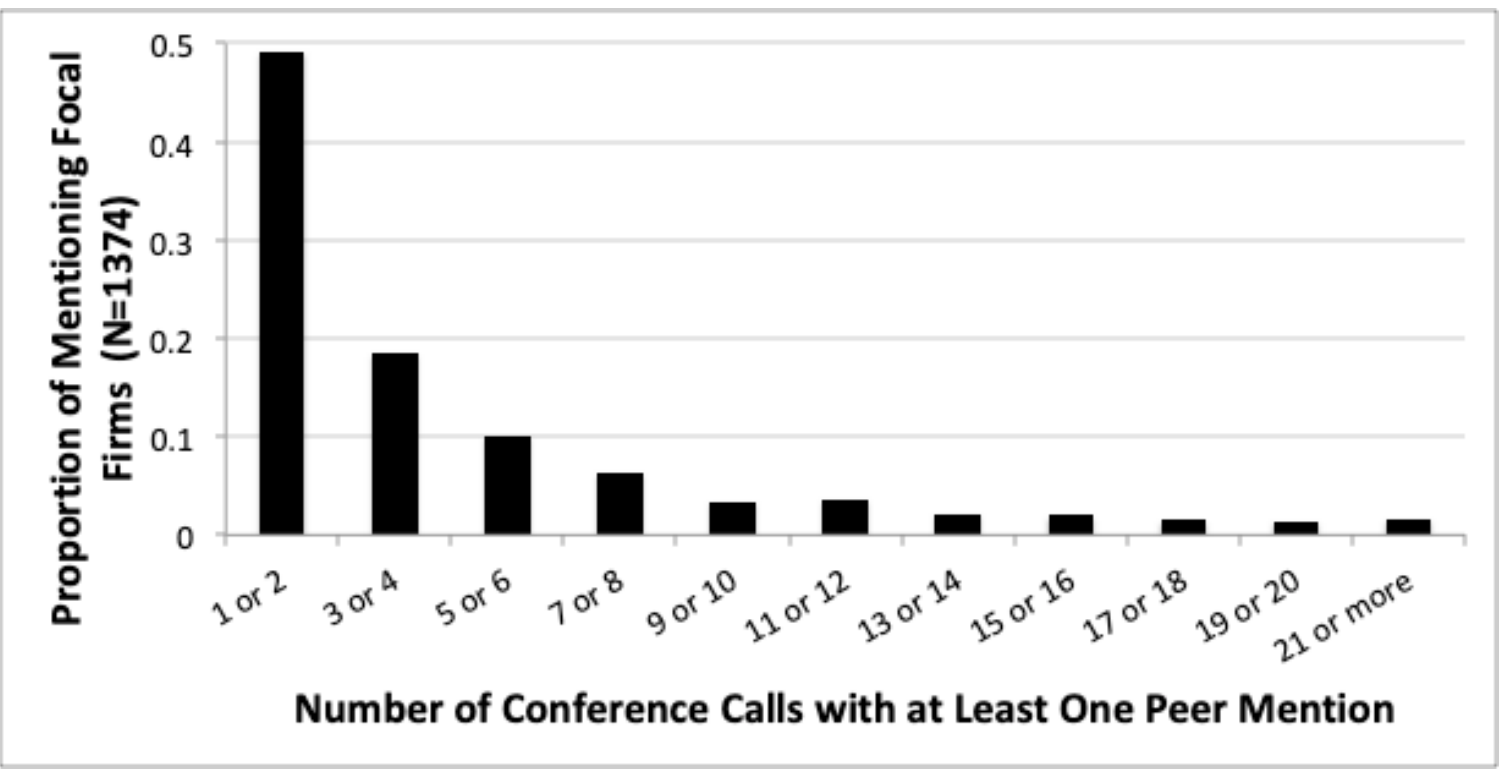


Figure 2: Do Peer Firm Mentions Vary Across Peer Firms?

This figure shows how peer firm mentions vary across peer firms. The sample of peer firms is restricted to only those firms that are mentioned at least once in the sample period (32 percent of all peer firms). Note that peer firms must be first mentioned by management.

Panel A: The Number of Unique Focal Firms that Mention the Peer Firm

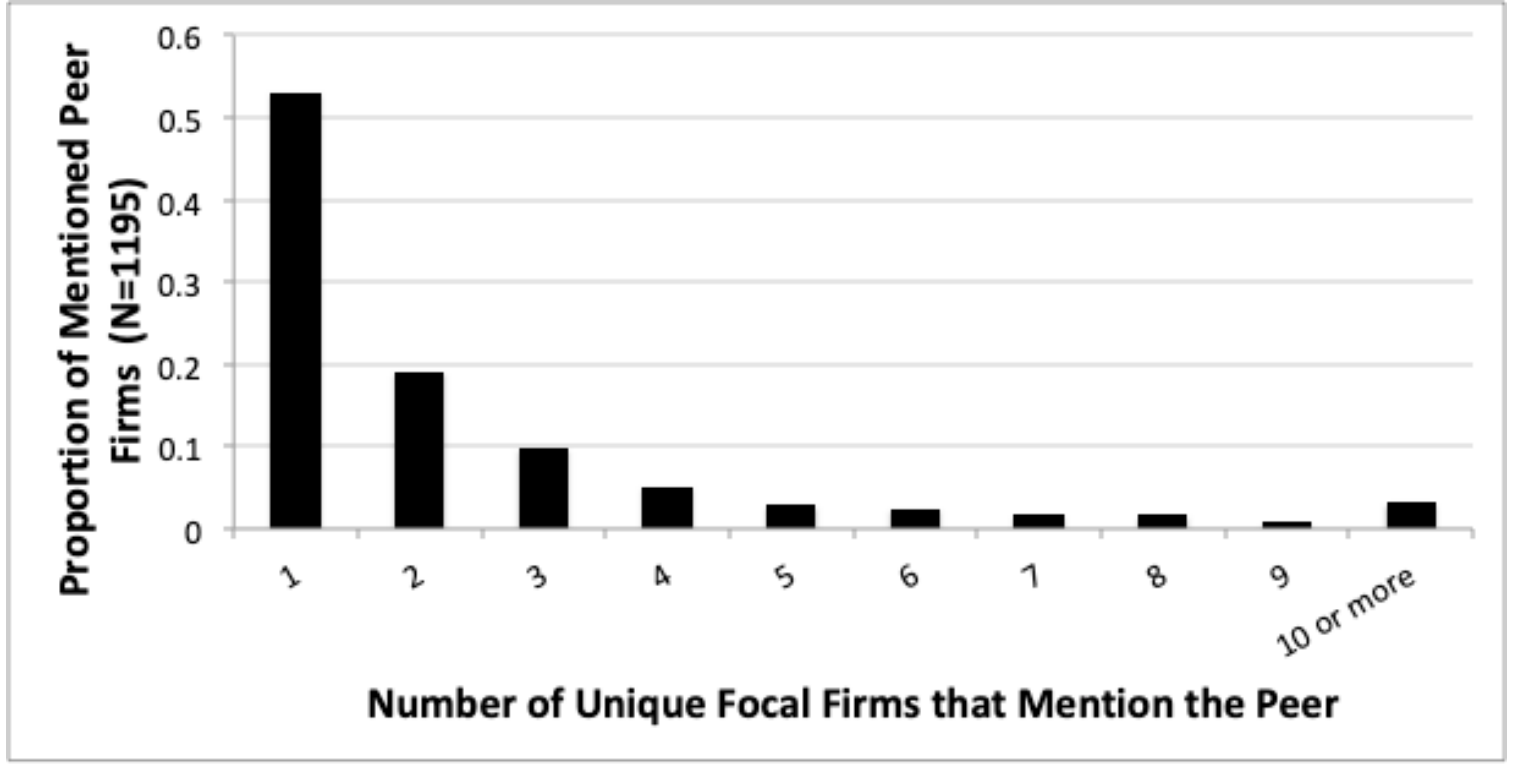

Panel B: The Number of Conference Calls in Which the Peer Firm is Mentioned

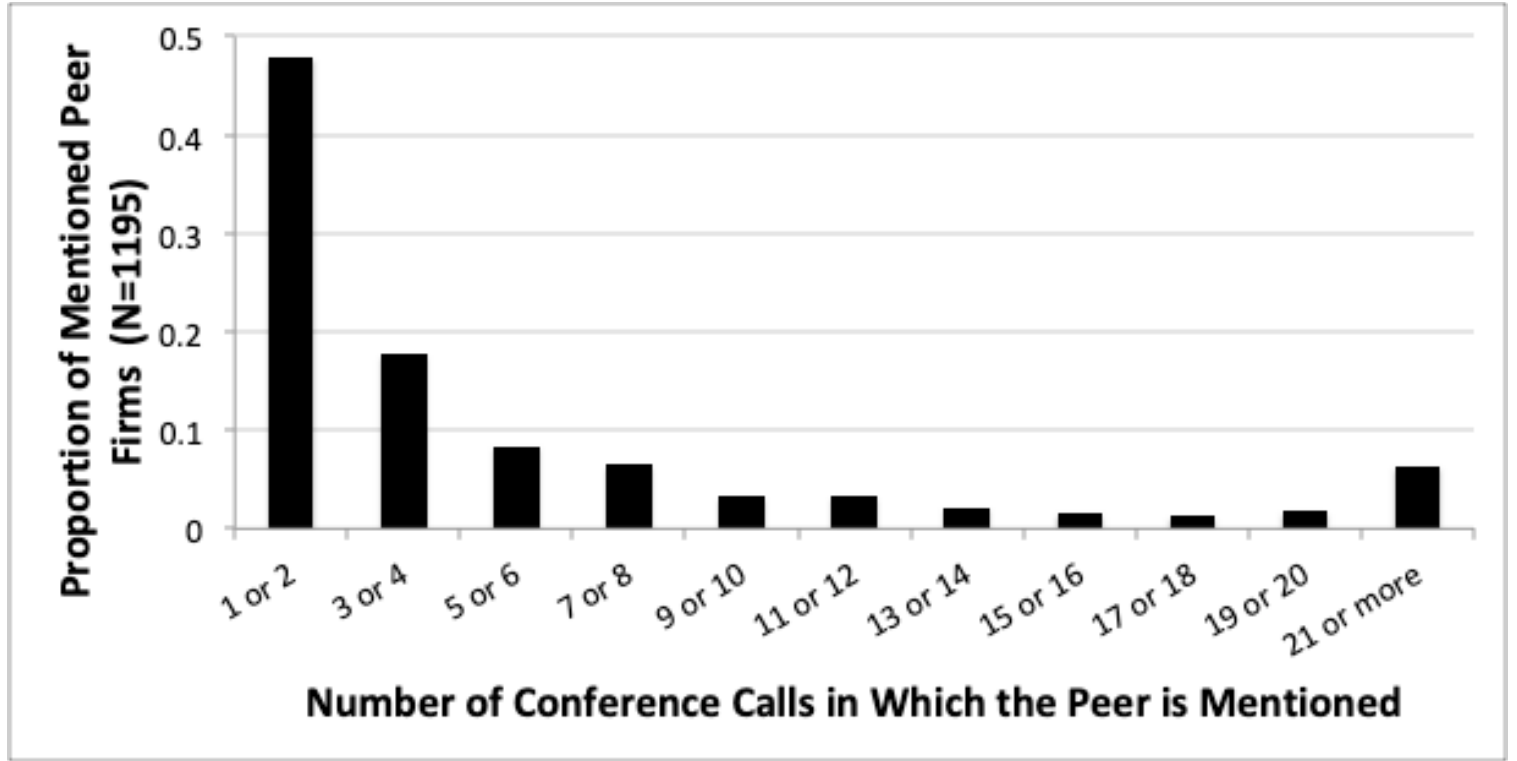




\section{Table 1: Which Focal Firm Characteristics are Associated with Peer Mentioning?}

This table displays the bivariate statistics for the focal firm quarters whose earnings conference calls contain at least one peer firm mention from managers and those that do not. All variables are defined in Appendix $\mathrm{C}$ and all continuous variables and NUM_PEERS are winsorized at the 1 and 99 percentiles. The superscripts $*, * *$, and $* * *$ denote significance at the 10,5 , and 1 percent levels respectively and are based on the t-test for mean differences, the Mann-Whitney test for median or distribution differences, and the z-test for proportion differences.

\begin{tabular}{|c|c|c|c|}
\hline & $\begin{array}{c}\text { (1) } \\
\text { Focal-Quarters } \\
\text { with Peer Mentions } \\
\text { Mean [Median] } \\
\text { \{Proportion\} }\end{array}$ & $\begin{array}{c}\text { (2) } \\
\text { Focal-Quarters } \\
\text { without Peer } \\
\text { Mentions } \\
\text { Mean [Median] } \\
\text { \{Proportion\} }\end{array}$ & $\begin{array}{c}(3) \\
\text { Difference } \\
(1)-(2)\end{array}$ \\
\hline FOCAL_P $2 B_{i, t}$ & $\begin{array}{c}3.7714 \\
{[2.4275]}\end{array}$ & $\begin{array}{c}3.4380 \\
{[2.3020]}\end{array}$ & $\begin{array}{c}0.3334 * * * \\
{\left[0.1255^{* * *}\right]}\end{array}$ \\
\hline$F O C A L_{-} R O A_{i, t}$ & $\begin{array}{l}-0.0208 \\
{[0.0272]}\end{array}$ & $\begin{array}{l}-0.0459 \\
{[0.0260]}\end{array}$ & $\begin{array}{c}0.0251 * * * \\
{[0.0012 * * *]}\end{array}$ \\
\hline FOCAL_RET $90_{i, t}$ & $\begin{array}{c}0.0422 \\
{[0.0559]}\end{array}$ & $\begin{array}{c}0.0385 \\
{[0.0514]}\end{array}$ & $\begin{array}{c}0.0037 \\
{[0.0045]}\end{array}$ \\
\hline$F O C A L_{-} N O N_{-} N E G \_S U R P_{i, t}$ & $\{0.6632\}$ & $\{0.6766\}$ & $\{-0.0134 * *\}$ \\
\hline$F O C A L_{-} S I Z E_{i, t}$ & $\begin{array}{c}7.7560 \\
{[7.7777]}\end{array}$ & $\begin{array}{c}7.1597 \\
{[7.1311]}\end{array}$ & $\begin{array}{c}0.5963 * * * \\
{[0.6466 * * *]}\end{array}$ \\
\hline$N U M_{-} P E E R S_{i, t}$ & $\begin{array}{c}17.6000 \\
{[20.0000]}\end{array}$ & $\begin{array}{l}13.1726 \\
{[9.0000]}\end{array}$ & $\begin{array}{c}4.4274 * * * \\
{[11 * * *]}\end{array}$ \\
\hline$T N I C \_S C O R E_{-} A V_{i, t}$ & $\begin{array}{c}0.1116 \\
{[0.0975]}\end{array}$ & $\begin{array}{c}0.1036 \\
{[0.0883]}\end{array}$ & $\begin{array}{c}0.0080^{* * *} \\
{[0.0092 * * *]}\end{array}$ \\
\hline FOCAL_REPORTS_LATER $R_{i, t}$ & $\{0.4227\}$ & $\{0.4186\}$ & $\{0.0041\}$ \\
\hline$N$ & 6033 & 28847 & \\
\hline
\end{tabular}




\section{Table 2: Descriptive Statistics}

Panels A and B display the summary statistics for the variables used in regression equations (1) and (2) respectively. All variables are defined in Appendix $C$ and all continuous variables and PEER_MENTION_COUNT are winsorized at the 1 and 99 percentiles.

\begin{tabular}{|c|c|c|c|c|c|c|}
\hline & $\mathbf{N}$ & Mean & Stdev & Q1 & Median & Q3 \\
\hline \multicolumn{7}{|c|}{ Panel A: Variables used in Regression Equation (1) for Table 3 Panel A } \\
\hline PEER_MENTION & 13664 & 0.5026 & 0.5000 & 0.0000 & 1.0000 & 1.0000 \\
\hline$P E E R_{-} B E T T E R_{-} P 2 B_{i, j, t}$ & 13664 & 0.4982 & 0.5000 & 0.0000 & 0.0000 & 1.0000 \\
\hline$P E E R \_B E T T E R_{-} R O A_{i, j, t}$ & 13664 & 0.5039 & 0.5000 & 0.0000 & 1.0000 & 1.0000 \\
\hline$P E E R_{-} B E T T E R_{-} R E T_{i, j, t}$ & 13664 & 0.5053 & 0.5000 & 0.0000 & 1.0000 & 1.0000 \\
\hline$S I Z E_{-} D I F F_{i, j, t}$ & 13664 & -0.0835 & 2.1931 & -1.5027 & -0.0714 & 1.3342 \\
\hline TNIC_SCORE $E_{i, j, t}$ & 13664 & 0.1332 & 0.1013 & 0.0767 & 0.1038 & 0.1527 \\
\hline PEER_REPORTS_FIRST $T_{i, j, t}$ & 13664 & 0.4932 & 0.5000 & 0.0000 & 0.0000 & 1.0000 \\
\hline \multicolumn{7}{|c|}{ Panel B: Variables used in Regression Equation (2) for Table 7 Panel A } \\
\hline$A B S_{-} P E E R_{-} C A R 2_{i, j, t}$ & 9012 & 0.0232 & 0.0236 & 0.0069 & 0.0158 & 0.0306 \\
\hline PEER_MENTION $N_{i, j, t}$ & 9012 & 0.4966 & 0.5000 & 0.0000 & 0.0000 & 1.0000 \\
\hline PEER_MENTION_COUNT $T_{i, j, t}$ & 9012 & 1.3943 & 2.6330 & 0.0000 & 0.0000 & 1.0000 \\
\hline BETTER_MENTION $N_{i, j, t}$ & 9012 & 0.2619 & 0.4397 & 0.0000 & 0.0000 & 1.0000 \\
\hline WORSE_MENTION $_{i, j, t}$ & 9012 & 0.2347 & 0.4238 & 0.0000 & 0.0000 & 0.0000 \\
\hline$A B S \_F O C A L \_E A \_S U R_{i, j, t}$ & 9012 & 0.0097 & 0.0238 & 0.0006 & 0.0019 & 0.0060 \\
\hline$F O C A L_{-} S I Z E_{i, j, t}$ & 9012 & 7.6181 & 2.0530 & 6.0550 & 7.5852 & 9.2030 \\
\hline$P E E R_{-} S I Z E_{i, j, t}$ & 9012 & 7.6308 & 2.1904 & 5.9964 & 7.6825 & 9.1754 \\
\hline$F O C A L_{-} P 2 B_{i, j, t}$ & 9012 & 4.0852 & 7.6677 & 1.4689 & 2.5332 & 4.6476 \\
\hline$P E E R_{-} P 2 B_{i, j, t}$ & 9012 & 3.7045 & 6.0765 & 1.4205 & 2.5016 & 4.5640 \\
\hline$T N I C \_S C O R E_{i, j, t}$ & 9012 & 0.1117 & 0.0484 & 0.0740 & 0.0966 & 0.1379 \\
\hline PEER_REPORTS_FIRST $T_{i, j, t}$ & 9012 & 0.5819 & 0.4933 & 0.0000 & 1.0000 & 1.0000 \\
\hline
\end{tabular}




\section{Table 3: Are Managers More Likely to Mention Better or Worse Performing Peers?}

Table 3 presents the results from logistic regression equation (1). In panel A (B), the dependent variable equals one if the peer firm is first mentioned by management in either (management discussion) section of the conference call, and zero if the peer firm is not mentioned by management or analysts. The independent variables of interest equal one if the peer firm's performance is at least as good as the focal firm's performance, and zero otherwise. Performance is measured as the price-to-book ratio, the return on assets ratio, or the 90-day prior stock return. The control variables are peer firm minus focal firm size, TNIC similarity score, an indicator variable denoting whether the peer firm reported its quarterly earnings before (one) or after (zero) the focal firm, and calendar quarter-year fixed effects. All variables are defined in Appendix C. Average discrete changes are presented in square brackets. Standard errors are clustered by focal firm and presented in parentheses. The superscripts $* * *$, and $* * *$ denote significance at the 10 , 5 , and 1 percent levels respectively.

Panel A: Management First Mentions Peer Firms in Either Section of the Conference Call

\begin{tabular}{|c|c|c|c|}
\hline VARIABLES & $\begin{array}{c}(1) \\
\text { PEER_MENTION } \\
\text { i,j,t }\end{array}$ & $\begin{array}{c}\text { (2) } \\
\text { PEER_MENTION } \\
\text { ME,j,t }\end{array}$ & $\begin{array}{c}\text { (3) } \\
\text { PEER_MENTION } \\
\text { i,j,t }\end{array}$ \\
\hline$P E E R_{-} B E T T E R_{-} P 2 B_{i, j, t}$ & $\begin{array}{c}0.1974^{* * *} \\
{\left[0.0427^{* * *}\right]} \\
(0.0525)\end{array}$ & & \\
\hline$P E E R \_B E T T E R_{-} R O A_{i, j, t}$ & & $\begin{array}{c}0.0901^{*} \\
{\left[0.0196^{*}\right]} \\
(0.0506)\end{array}$ & \\
\hline$P E E R_{-} B E T T E R_{-} R E T_{i, j, t}$ & & & $\begin{array}{c}0.1388^{* * *} \\
{\left[0.0300^{* * *}\right]} \\
(0.0336)\end{array}$ \\
\hline$S I Z E_{-} D I F F_{i, j, t}$ & $\begin{array}{c}0.2821 * * * \\
{\left[0.1312^{* * *}\right]} \\
(0.0175)\end{array}$ & $\begin{array}{c}0.2764 * * * \\
{[0.1289 * * *]} \\
(0.0177)\end{array}$ & $\begin{array}{c}0.2815^{* * *} \\
{\left[0.1311^{* * *}\right]} \\
(0.0175)\end{array}$ \\
\hline$T N I C \_S C O R E_{i, j, t}$ & $\begin{array}{c}8.0881^{* * *} \\
{\left[0.1712^{* * *}\right]} \\
(0.7252)\end{array}$ & $\begin{array}{c}8.0743^{* * *} \\
{\left[0.1712^{* * *}\right]} \\
(0.7194)\end{array}$ & $\begin{array}{c}8.1263^{* * *} \\
{\left[0.1721^{* * *}\right]} \\
(0.7274)\end{array}$ \\
\hline PEER_REPORTS_FIRST $T_{i, j, t}$ & $\begin{array}{c}0.0739 \\
{[0.0160]} \\
(0.0600)\end{array}$ & $\begin{array}{c}0.0834 \\
{[0.0181]} \\
(0.0597)\end{array}$ & $\begin{array}{c}0.0937 \\
{[0.0203]} \\
(0.0608)\end{array}$ \\
\hline CONSTANT & $\begin{array}{c}-1.0403^{* * *} \\
(0.1371)\end{array}$ & $\begin{array}{c}-0.9764^{* * *} \\
(0.1340)\end{array}$ & $\begin{array}{c}-1.0184 * * * \\
(0.1295)\end{array}$ \\
\hline
\end{tabular}


Observations

Calendar Quarter-Year FE

Sensitivity, Specificity

McFadden's R2

Log Likelihood
13,664

Yes

$0.643,0.654$

0.107

$-8457$
13,664

Yes

$0.640,0.651$

0.106

$-8469$
13,664

Yes

$0.641,0.652$

0.106

$-8465$

Panel B: Management First Mentions Peer Firms in the Discussion Section of the Conference Call

\begin{tabular}{|c|c|c|c|}
\hline VARIABLES & $\begin{array}{c}(1) \\
P E E R \_M E N T I O N_{i, j, t}\end{array}$ & $\begin{array}{c}(2) \\
\text { PEER_MENTION } \\
{ }_{i, j, t}\end{array}$ & $\begin{array}{c}(3) \\
\text { PEER_MENTION } \\
i, j, t\end{array}$ \\
\hline$P E E R \_B E T T E R \_P 2 B_{i, j, t}$ & $\begin{array}{c}0.1623 * * * \\
{[0.0354 * * *]} \\
(0.0599)\end{array}$ & & \\
\hline$P E E R \_B E T T E R \_R O A_{i, j, t}$ & & $\begin{array}{c}0.0761 \\
{[0.0166]} \\
(0.0599)\end{array}$ & \\
\hline$P E E R_{-} B E T T E R_{-} R E T_{i, j, t}$ & & & $\begin{array}{c}0.1407 * * * \\
{[0.0307 * * *]} \\
(0.0373)\end{array}$ \\
\hline$S I Z E_{-} D I F F_{i, j, t}$ & $\begin{array}{c}0.2427 * * * \\
{[0.1137 * * *]} \\
(0.0190)\end{array}$ & $\begin{array}{c}0.2375 * * * \\
{[0.1114 * * *]} \\
(0.0192)\end{array}$ & $\begin{array}{c}0.2416 * * * \\
{[0.1132 * * *]} \\
(0.0190)\end{array}$ \\
\hline$T N I C \_S C O R E_{i, j, t}$ & $\begin{array}{c}8.1615 * * * \\
{[0.1945 * * *]} \\
(0.8433)\end{array}$ & $\begin{array}{c}8.1407 * * * \\
{[0.1943 * * *]} \\
(0.8348)\end{array}$ & $\begin{array}{c}8.1948 * * * \\
{[0.1953 * * *]} \\
(0.8448)\end{array}$ \\
\hline PEER_REPORTS_FIRST $T_{i, j, t}$ & $\begin{array}{c}0.0764 \\
{[0.0167]} \\
(0.0691)\end{array}$ & $\begin{array}{c}0.0848 \\
{[0.0185]} \\
(0.0683)\end{array}$ & $\begin{array}{c}0.0943 \\
{[0.0206]} \\
(0.0696)\end{array}$ \\
\hline CONSTANT & $\begin{array}{c}-0.9694 * * * \\
(0.1412)\end{array}$ & $\begin{array}{c}-0.9233 * * * \\
(0.1406)\end{array}$ & $\begin{array}{c}-0.9696 * * * \\
(0.1336)\end{array}$ \\
\hline $\begin{array}{l}\text { Observations } \\
\text { Calendar Ouarter-Year FF }\end{array}$ & $\begin{array}{c}10,206 \\
\text { Yes }\end{array}$ & $\begin{array}{c}10,206 \\
\text { Yes }\end{array}$ & $\begin{array}{c}10,206 \\
\text { Yes }\end{array}$ \\
\hline Sensitivity, Specificity & $0.622,0.667$ & $0.617,0.667$ & $0.620,0.671$ \\
\hline McFadden's R2 & 0.103 & 0.102 & 0.102 \\
\hline Log Likelihood & -6349 & -6355 & -6351 \\
\hline
\end{tabular}




\section{Table 4: Are Managers More Likely to Mention Better or Worse Performing Competitor and Non-Competitor Peer Firms?}

Table 4 presents the results from logistic regression equation (1). Panel A (B) restricts the sample to competitor (non-competitor) peer mentions and their randomly selected control observations. In panel A (B), the dependent variable equals one if the competitor (non-competitor) firm is first mentioned by management in either section of the conference call, and zero if the peer firm is not mentioned by management or analysts. The independent variables of interest equal one if the peer firm's performance is at least as good as the focal firm's performance, and zero otherwise. Performance is measured as the price-to-book ratio, the return on assets ratio, or the 90-day prior stock return. The control variables are peer firm minus focal firm size, TNIC similarity score, an indicator variable denoting whether the peer firm reported its quarterly earnings before (one) or after (zero) the focal firm, and calendar quarter-year fixed effects. All variables are defined in Appendix $C$ and the classification of peer firm mentions into competitors and non-competitors is explained in Appendix D. Average discrete changes are presented in square brackets. Standard errors are clustered by focal firm and presented in parentheses. The superscripts $* * *$, and $* * *$ denote significance at the 10,5 , and 1 percent levels respectively.

Panel A: Management First Mentions Competitor Firms in Either Section of the Conference Call

\begin{tabular}{lccc}
\hline & $(1)$ & $(2)$ & $(3)$ \\
VARIABLES & & & \\
PEER_BETTER_P $2 B_{i, j, t}$ & $0.2890^{* * *}$ & & \\
& {$\left[0.0570^{* * *}\right]$} & & \\
PEER_BETTER_ROA $A_{i, j, t}$ & $(0.0834)$ & & \\
& & & \\
& & $0.1553^{*}$ & \\
PEER_BETTER_RET $T_{i, j, t}$ & & $\left.0.0309^{*}\right]$ & \\
& & $(0.0832)$ & $0.2163^{* * *}$ \\
& & & {$\left[0.0426^{* * *}\right]$} \\
SIZE_DIFF $F_{i, j, t}$ & & & $(0.0597)$ \\
& & & $0.4123^{* * *}$ \\
TNIC_SCORE $E_{i, j, t}$ & $0.4135^{* * *}$ & $0.4016^{* * *}$ & {$\left[0.1828^{* * *}\right]$} \\
& $\left(0.1829^{* * *}\right]$ & {$\left[0.1786^{* * *}\right]$} & $(0.0284)$ \\
& $(0.0281)$ & $(0.0286)$ & $11.8230^{* * *}$ \\
PEER_REPORTS_FIRST $T_{i, j, t}$ & $11.7322^{* * *}$ & $11.7269^{* * *}$ & {$\left[0.1201^{* * *}\right]$} \\
& {$\left[0.1190^{* * *}\right]$} & {$\left[0.1193^{* * *}\right]$} & $(1.0038)$ \\
& $(0.9976)$ & $(0.9920)$ & $0.1751^{* *}$ \\
& $0.1462^{*}$ & $0.1633^{*}$ & {$\left[0.0348^{*}\right]$}
\end{tabular}


Observations

5,091
Yes

(0.2067)

(0.2078)

Calendar Quarter-Year FE

$0.703,0.676$

5,091

5,091

Sensitivity, Specificity

0.169

Yes

Yes

McFadden's R2

$-2932$

$0.700,0.680$

$0.703,0.684$

0.167

0.168

Log Likelihood

$-2939$

$-2936$

Panel B: Management First Mentions Non-Competitor Firms in Either Section of the Conference Call

\begin{tabular}{|c|c|c|c|}
\hline VARIABLES & $\begin{array}{c}(1) \\
P E E R_{-} M E N T I O N_{i, j, t}\end{array}$ & $\begin{array}{c}(2) \\
\text { PEER_MENTION } \\
i, j, t\end{array}$ & $\begin{array}{c}(3) \\
\text { PEER_MENTION } \\
{ }_{i, j, t}\end{array}$ \\
\hline$P E E R \_B E T T E R_{-} P 2 B_{i, j, t}$ & $\begin{array}{c}0.2666^{* *} \\
{\left[0.0553^{* * *}\right]} \\
(0.1037)\end{array}$ & & \\
\hline$P E E R_{-} B E T T E R_{-} R O A_{i, j, t}$ & & $\begin{array}{c}0.0692 \\
{[0.0144]} \\
(0.1019)\end{array}$ & \\
\hline$P E E R_{-} B E T T E R_{-} R E T_{i, j, t}$ & & & $\begin{array}{c}0.1715^{* * *} \\
{\left[0.0356^{* * *}\right]} \\
(0.0621)\end{array}$ \\
\hline$S I Z E_{-} D I F F_{i, j, t}$ & $\begin{array}{c}0.2375^{* * *} \\
{\left[0.1093^{* * *}\right]} \\
(0.0316)\end{array}$ & $\begin{array}{c}0.2314^{* * *} \\
{[0.1069 * * *]} \\
(0.0318)\end{array}$ & $\begin{array}{c}0.2362^{* * *} \\
{\left[0.1089^{* * *}\right]} \\
(0.0317)\end{array}$ \\
\hline TNIC_SCORE $E_{i, j, t}$ & $\begin{array}{c}10.2824 * * * \\
{[0.2486 * * *]} \\
(1.7332)\end{array}$ & $\begin{array}{c}10.2605^{* * *} \\
{\left[0.2488^{* * *}\right]} \\
(1.7090)\end{array}$ & $\begin{array}{c}10.3324^{* * *} \\
{\left[0.2500^{* * *}\right]} \\
(1.7187)\end{array}$ \\
\hline PEER_REPORTS_FIRST $T_{i, j, t}$ & $\begin{array}{c}0.1107 \\
{[0.0230]} \\
(0.1056)\end{array}$ & $\begin{array}{c}0.1274 \\
{[0.0266]} \\
(0.1070)\end{array}$ & $\begin{array}{c}0.1334 \\
{[0.0278]} \\
(0.1074)\end{array}$ \\
\hline CONSTANT & $\begin{array}{c}-0.9675^{* * *} \\
(0.2567)\end{array}$ & $\begin{array}{c}-0.8554 * * * \\
(0.2486)\end{array}$ & $\begin{array}{c}-0.9333 * * * \\
(0.2414)\end{array}$ \\
\hline $\begin{array}{l}\text { Observations } \\
\text { Calendar Quarter-Year FE }\end{array}$ & $\begin{array}{c}3,875 \\
\text { Yes }\end{array}$ & $\begin{array}{c}3,875 \\
\text { Yes }\end{array}$ & $\begin{array}{c}3,875 \\
\text { Yes }\end{array}$ \\
\hline Sensitivity, Specificity & $0.644,0.716$ & $0.646,0.712$ & $0.654,0.713$ \\
\hline McFadden's R2 & 0.141 & 0.138 & 0.139 \\
\hline Log Likelihood & -2308 & -2315 & -2312 \\
\hline
\end{tabular}




\section{Table 5: Are Managers More Likely to Mention Better or Worse Performing Peers}

\section{Around Upward Perception Events?}

Table 5 presents the results from logistic regression equation (1). Panel A (B) restricts the sample to upward (non-upward) perception event periods for the focal firm. The dependent variable equals one if the peer firm is first mentioned by management in either section of the conference call, and zero if the peer firm is not mentioned by management or analysts. The independent variables of interest equal one if the peer firm's performance is at least as good as the focal firm's performance, and zero otherwise. Performance is measured as the price-to-book ratio, the return on assets ratio, or the 90-day prior stock return. The control variables are peer firm minus focal firm size, TNIC similarity score, an indicator variable denoting whether the peer firm reported its quarterly earnings before (one) or after (zero) the focal firm, and calendar quarter-year fixed effects. All variables are defined in Appendix $C$ and the classification of focal periods into upward and non-upward perception periods is also explained in Appendix C. Average discrete changes are presented in square brackets. Standard errors are clustered by focal firm and presented in parentheses. The superscripts *, $* *$, and $* * *$ denote significance at the 10,5 , and 1 percent levels respectively.

Panel A: Management's Mentions of Peer Firms Around Upward Perception Periods

\begin{tabular}{|c|c|c|c|}
\hline VARIABLES & $\begin{array}{c}(1) \\
\text { PEER_MENTION } \\
\text { P }\end{array}$ & $\begin{array}{c}(2) \\
\text { PEER_MENTION } \\
\text { i,j,t }\end{array}$ & $\begin{array}{c}\text { (3) } \\
\text { PEER_MENTION } \\
i, j, t\end{array}$ \\
\hline$P E E R \_B E T T E R_{-} P 2 B_{i, j, t}$ & $\begin{array}{c}0.1469 * * \\
{\left[0.0315^{* *}\right]} \\
(0.0677)\end{array}$ & & \\
\hline$P E E R \_B E T T E R_{-} R O A_{i, j, t}$ & & $\begin{array}{c}-0.0518 \\
{[-0.0111]} \\
(0.0645)\end{array}$ & \\
\hline$P E E R_{-} B E T T E R_{-} R E T_{i, j, t}$ & & & $\begin{array}{c}0.1101^{* *} \\
{\left[0.0236^{* *}\right]} \\
(0.0497)\end{array}$ \\
\hline$S I Z E_{-} D I F F_{i, j, t}$ & $\begin{array}{c}0.3156^{* * *} \\
{\left[0.1439^{* * *}\right]} \\
(0.0221)\end{array}$ & $\begin{array}{c}0.3178^{* * *} \\
{\left[0.1450^{* * *}\right]} \\
(0.0225)\end{array}$ & $\begin{array}{c}0.3157^{* * *} \\
{\left[0.1440^{* * *}\right]} \\
(0.0223)\end{array}$ \\
\hline$T N I C \_S C O R E_{i, j, t}$ & $\begin{array}{c}7.5607^{* * *} \\
{\left[0.1438^{* * *}\right]} \\
(0.6253)\end{array}$ & $\begin{array}{c}7.5851^{* * *} \\
{\left[0.1444^{* * *}\right]} \\
(0.6246)\end{array}$ & $\begin{array}{c}7.5838^{* * *} \\
{\left[0.1443^{* * *}\right]} \\
(0.6258)\end{array}$ \\
\hline PEER_REPORTS_FIRST $T_{i, j, t}$ & $\begin{array}{c}0.1368^{*} \\
{\left[0.0295^{*}\right]} \\
(0.0734)\end{array}$ & $\begin{array}{c}0.1576^{* *} \\
{\left[0.0340^{* *}\right]} \\
(0.0733)\end{array}$ & $\begin{array}{c}0.1466 * * \\
{[0.0316 *]} \\
(0.0745)\end{array}$ \\
\hline
\end{tabular}


Observations

Calendar Quarter-Year FE

5,939
Yes

5,939

5,939

Sensitivity, Specificity

$0.650,0.654$

Yes

Yes

McFadden's R2

0.112

$0.653,0.656$

$0.653,0.655$

$-3657$

0.111

0.111

Log Likelihood

$-3660$

$-3658$

Panel B: Management's Mentions of Peer Firms Around Non-Upward Perception Periods

\begin{tabular}{|c|c|c|c|}
\hline VARIABLES & $\begin{array}{c}(1) \\
P E E R_{-} M E N T I O N_{i, j, t}\end{array}$ & $\begin{array}{c}(2) \\
\text { PEER_MENTION } \\
i, j, t\end{array}$ & $\begin{array}{c}(3) \\
\text { PEER_MENTION } \\
i, j, t\end{array}$ \\
\hline$P E E R_{-} B E T T E R_{-} P 2 B_{i, j, t}$ & $\begin{array}{c}0.2210^{* * *} \\
{[0.0478 * * *]} \\
(0.0677)\end{array}$ & & \\
\hline$P E E R \_B E T T E R \_R O A_{i, j, t}$ & & $\begin{array}{c}0.1999 * * * \\
{[0.0434 * * *]} \\
(0.0660)\end{array}$ & \\
\hline$P E E R_{-} B E T T E R_{-} R E T_{i, j, t}$ & & & $\begin{array}{c}0.1656^{* * *} \\
{\left[0.0358^{* * *}\right]} \\
(0.0478)\end{array}$ \\
\hline$S I Z E_{-} D I F F_{i, j, t}$ & $\begin{array}{c}0.2776^{* * *} \\
{\left[0.1275^{* * *}\right]} \\
(0.0205)\end{array}$ & $\begin{array}{c}0.2684^{* * *} \\
{\left[0.1235^{* * *}\right]} \\
(0.0207)\end{array}$ & $\begin{array}{c}0.2770^{* * *} \\
{\left[0.1274^{* * *}\right]} \\
(0.0205)\end{array}$ \\
\hline$T N I C \_S C O R E_{i, j, t}$ & $\begin{array}{c}9.2847^{* * *} \\
{\left[0.2042^{* * *}\right]} \\
(1.2328)\end{array}$ & $\begin{array}{c}9.2333^{* * *} \\
{\left[0.2033^{* * *}\right]} \\
(1.2192)\end{array}$ & $\begin{array}{c}9.3621^{* * *} \\
{\left[0.2059^{* * *}\right]} \\
(1.2337)\end{array}$ \\
\hline PEER_REPORTS_FIRST $T_{i, j, t}$ & $\begin{array}{c}-0.0108 \\
{[-0.0023]} \\
(0.0740)\end{array}$ & $\begin{array}{c}-0.0127 \\
{[-0.0027]} \\
(0.0738)\end{array}$ & $\begin{array}{c}0.0157 \\
{[0.0034]} \\
(0.0742)\end{array}$ \\
\hline CONSTANT & $\begin{array}{c}-1.0934 * * * \\
(0.1963)\end{array}$ & $\begin{array}{c}-1.0694^{* * *} \\
(0.1909)\end{array}$ & $\begin{array}{c}-1.0822 * * * \\
(0.1881)\end{array}$ \\
\hline Observations & 7,393 & 7,393 & 7,393 \\
\hline Calendar Quarter-Year FE & Yes & Yes & Yes \\
\hline Sensitivity, Specificity & $0.646,0.671$ & $0.641,0.668$ & $0.648,0.665$ \\
\hline McFadden's R2 & 0.110 & 0.110 & 0.109 \\
\hline Log Likelihood & -4560 & -4562 & -4564 \\
\hline
\end{tabular}




\section{Table 6: Are Analysts More Likely to Mention Better or Worse Performing Peers}

\section{Around Upward Perception Events?}

Table 6 presents the results from logistic regression equation (1). Panel A (B) restricts the sample to upward (non-upward) perception event periods for the focal firm. The dependent variable equals one if the peer firm is first mentioned by analysts in the conference call, and zero if the peer firm is not mentioned by management or analysts. The independent variables of interest equal one if the peer firm's performance is at least as good as the focal firm's performance, and zero otherwise. Performance is measured as the price-to-book ratio, the return on assets ratio, or the 90-day prior stock return. The control variables are peer firm minus focal firm size, TNIC similarity score, an indicator variable denoting whether the peer firm reported its quarterly earnings before (one) or after (zero) the focal firm, and calendar quarter-year fixed effects. All variables are defined in Appendix $C$ and the classification of focal periods into upward and non-upward perception periods is also explained in Appendix C. Average discrete changes are presented in square brackets. Standard errors are clustered by focal firm and presented in parentheses. The superscripts $*, * *$, and ${ }^{* * *}$ denote significance at the 10,5 , and 1 percent levels respectively.

Panel A: Analysts' Mentions of Peer Firms Around Upward Perception Periods

\begin{tabular}{|c|c|c|c|}
\hline VARIABLES & $\begin{array}{c}(1) \\
\text { PEER_MENTION } \\
i, j, t\end{array}$ & $\begin{array}{c}(2) \\
\text { PEER_MENTION } \\
i, j, t\end{array}$ & $\begin{array}{c}(3) \\
\text { PEER_MENTION } \\
i, j, t\end{array}$ \\
\hline \multirow{3}{*}{$P E E R \_B E T T E R_{-} P 2 B_{i, j, t}$} & $0.2860 * *$ & & \\
\hline & {$[0.0553 * *]$} & & \\
\hline & $(0.1183)$ & & \\
\hline \multirow{3}{*}{$P E E R \_B E T T E R \_R O A_{i, j, t}$} & & $0.3100 * * *$ & \\
\hline & & {$[0.0606 * *]$} & \\
\hline & & $(0.1196)$ & \\
\hline \multirow[t]{3}{*}{$P E E R \_B E T T E R_{-} R E T_{i, j, t}$} & & & -0.0350 \\
\hline & & & {$[-0.0068]$} \\
\hline & & & $(0.1186)$ \\
\hline \multirow[t]{3}{*}{$S I Z E_{-} D I F F_{i, j, t}$} & $0.4554 * * *$ & $0.4360 * * *$ & $0.4517^{* * *}$ \\
\hline & {$\left[0.1818^{* * *}\right]$} & {$\left[0.1746^{* * *}\right]$} & {$\left[0.1812^{* * *}\right]$} \\
\hline & $(0.0375)$ & $(0.0379)$ & $(0.0375)$ \\
\hline \multirow[t]{3}{*}{$T N I C_{-} S C O R E_{i, j, t}$} & $11.8060 * * *$ & $11.9448^{* * *}$ & $11.9124^{* * *}$ \\
\hline & {$\left[0.1047^{* * *}\right]$} & {$[0.1059 * * *]$} & {$[0.1061 * * *]$} \\
\hline & $(1.4295)$ & $(1.4371)$ & $(1.4324)$ \\
\hline \multirow{3}{*}{$P E E R \_R E P O R T S_{-} F I R S T_{i, j, t}$} & $0.4380 * * *$ & $0.4293 * * *$ & $0.4746 * * *$ \\
\hline & {$[0.0864 * * *]$} & {$\left[0.0847^{* * *}\right]$} & {$\left[0.0941^{* * *}\right]$} \\
\hline & $(0.1347)$ & $(0.1354)$ & $(0.1356)$ \\
\hline
\end{tabular}


Observations

$\begin{array}{cc}1,364 & 1,364 \\ \text { Yes } & \text { Yes } \\ 0.731,0.701 & 0.734,0.700 \\ 0.183 & 0.183 \\ -772.7 & -772.4\end{array}$

Panel B: Analysts' Mentions of Peer Firms Around Non-Upward Perception Periods

\begin{tabular}{|c|c|c|c|}
\hline VARIABLES & $\begin{array}{c}(1) \\
P E E R_{-} M E N T I O N_{i, j, t}\end{array}$ & $\begin{array}{c}(2) \\
\text { PEER_MENTION } \\
i, j, t\end{array}$ & $\begin{array}{c}(3) \\
\text { PEER_MENTION } \\
{ }_{i, j, t}\end{array}$ \\
\hline \multirow[t]{3}{*}{$P E E R \_B E T T E R \_P 2 B_{i, j, t}$} & $0.2225^{* *}$ & & \\
\hline & {$[0.0440 * *]$} & & \\
\hline & $(0.0990)$ & & \\
\hline \multirow{3}{*}{$P E E R \_B E T T E R \_R O A_{i, j, t}$} & & -0.0531 & \\
\hline & & {$[-0.0105]$} & \\
\hline & & (0.1069) & \\
\hline \multirow[t]{3}{*}{$P E E R_{-} B E T T E R_{-} R E T_{i, j, t}$} & & & -0.0567 \\
\hline & & & {$[-0.0112]$} \\
\hline & & & $(0.0841)$ \\
\hline \multirow[t]{3}{*}{$S I Z E_{-} D I F F_{i, j, t}$} & $0.4621 * * *$ & $0.4628 * * *$ & $0.4601 * * *$ \\
\hline & {$\left[0.1778^{* * *}\right]$} & {$\left[0.1785^{* * *}\right]$} & {$\left[0.1775^{* * *}\right]$} \\
\hline & $(0.0325)$ & $(0.0330)$ & $(0.0323)$ \\
\hline \multirow[t]{3}{*}{$T N I C \_S C O R E_{i, j, t}$} & $13.1086 * * *$ & $13.1270 * * *$ & $13.1335 * * *$ \\
\hline & {$\left[0.1032^{* * *}\right]$} & {$\left[0.1036^{* * *}\right]$} & {$\left[0.1036^{* * *}\right]$} \\
\hline & $(1.6826)$ & (1.6982) & $(1.6983)$ \\
\hline \multirow[t]{3}{*}{ PEER_REPORTS_FIRST $T_{i, j, t}$} & $0.2597^{* *}$ & $0.2885^{* * *}$ & $0.2835^{* * *}$ \\
\hline & {$[0.0519 * *]$} & {$[0.0579 * * *]$} & {$\left[0.0568^{* * *}\right]$} \\
\hline & $(0.1047)$ & $(0.1044)$ & $(0.1043)$ \\
\hline \multirow[t]{2}{*}{ CONSTANT } & $-1.3323 * * *$ & $-1.2249 * * *$ & $-1.2162 * * *$ \\
\hline & $(0.2973)$ & $(0.3018)$ & $(0.3001)$ \\
\hline Observations & 2,247 & 2,247 & 2,247 \\
\hline Calendar Quarter-Year FE & Yes & Yes & Yes \\
\hline Sensitivity, Specificity & $0.723,0.677$ & $0.712,0.676$ & $0.713,0.678$ \\
\hline McFadden's R2 & 0.166 & 0.164 & 0.164 \\
\hline Log Likelihood & -1299 & -1302 & -1301 \\
\hline
\end{tabular}




\section{Table 7: Are Peer Firm Mentions by Management Informative to Peer Firm Equity Investors?}

Table 7 presents the results from ordinary least squares regression equation (2). Panel A (B) uses the sample of peer mentions in which the peer firm is first mentioned by management in either (management discussion) section of the conference call. The dependent variable is the peer firm's absolute cumulative abnormal return measured over $(0,+1)$ where day 0 is the focal firm's earnings conference call date. The independent variables of interest include an indicator variable denoting whether the peer firm is first mentioned by management (one) or not mentioned at all (zero); the number of times the peer is mentioned by management; and two indicator variables in which the first (second) variable denotes whether a better (worse) performing peer is first mentioned by management or not. The control variables are focal and peer firm sizes, focal and peer firm price-to-book ratios, TNIC similarity score, an indicator variable denoting whether the peer firm reported its quarterly earnings before (one) or after (zero) the focal firm, and calendar quarter-year fixed effects. All variables are defined in Appendix C. Standard errors are clustered by conference call and presented in parentheses. The superscripts $*, * *$, and $* * *$ denote significance at the 10,5 , and 1 percent levels respectively.

Panel A: Management First Mentions Peer Firms in Either Section of the Conference Call

VARIABLES

PEER_MENTION

PEER_MENTION_COUNT $T_{i, j, t}$

BETTER_MENTION $N_{i, j, t}$

WORSE_MENTION

$A B S \_F O C A L \_E A \_S U R_{i, j, t}$

FOCAL_SIZE $E_{i, j, t}$

PEER_SIZE $E_{i, j, t}$

FOCAL_P $2 B_{i, j, t}$

PEER_P $2 B_{i, j, t}$

TNIC_SCORE $E_{i, j, t}$
(1)

$A B S_{-} P E E R_{-} C A R 2_{i, j, t}$

$0.00078 *$

(0.00047)

$$
\begin{gathered}
0.04818^{* * *} \\
(0.01176) \\
-0.00001 \\
(0.00014) \\
-0.00281^{* * *} \\
(0.00014) \\
-0.00005^{*} \\
(0.00003) \\
-0.00001 \\
(0.00004) \\
0.03117^{* * *} \\
(0.00527)
\end{gathered}
$$$$
\text { (0.00527) }
$$

(2)

(3)

$A B S_{-} P E E R_{-} C A R 2_{i, j, t} \quad$ ABS_PEER_CAR2 $2_{i, j, t}$




\begin{tabular}{lccc} 
PEER_REPORTS_FIRST $i, j, t$ & $-0.00213^{* * *}$ & $-0.00213^{* * *}$ & $-0.00196^{* * *}$ \\
& $(0.00055)$ & $(0.00055)$ & $(0.00055)$ \\
CONSTANT & $0.04275^{* * *}$ & $0.04287^{* * *}$ & $0.04272^{* * *}$ \\
& $(0.00327)$ & $(0.00326)$ & $(0.00330)$ \\
Observations & & & \\
Calendar Quarter-Year FE & 9,012 & 9,012 & 9,012 \\
Adjusted R-squared & Yes & Yes & Yes \\
\hline
\end{tabular}

Panel B: Management First Mentions Peer Firms in the Discussion Section of the Conference Call

\begin{tabular}{|c|c|c|c|}
\hline VARIABLES & $\begin{array}{c}(1) \\
A B S_{-} P E E R_{-} C A R 2_{i, j, t}\end{array}$ & $\begin{array}{c}(2) \\
A B S_{-} P E E R_{-} C A R 2_{i, j, t}\end{array}$ & $\begin{array}{c}\text { (3) } \\
A B S \_P E E R \_C A R 2_{i, j, t}\end{array}$ \\
\hline PEER_MENTION $N_{i, j, t}$ & $\begin{array}{c}0.00090 \\
(0.00056)\end{array}$ & & \\
\hline PEER_MENTION_COUNT $T_{i, j, t}$ & & $\begin{array}{l}0.00025 * \\
(0.00013)\end{array}$ & \\
\hline BETTER_MENTION $N_{i, j, t}$ & & & $\begin{array}{l}-0.00013 \\
(0.00068)\end{array}$ \\
\hline WORSE_MENTION $N_{i, j, t}$ & & & $\begin{array}{c}0.00191^{* * *} \\
(0.00070)\end{array}$ \\
\hline$A B S_{-} F O C A L_{-} E A_{-} S U R_{i, j, t}$ & $\begin{array}{c}0.04380 * * * \\
(0.01290)\end{array}$ & $\begin{array}{c}0.04382^{* * *} \\
(0.01292)\end{array}$ & $\begin{array}{c}0.04609 * * * \\
(0.01290)\end{array}$ \\
\hline$F O C A L \_S I Z E_{i, j, t}$ & $\begin{array}{l}-0.00007 \\
(0.00017)\end{array}$ & $\begin{array}{l}-0.00009 \\
(0.00017)\end{array}$ & $\begin{array}{l}-0.00008 \\
(0.00017)\end{array}$ \\
\hline$P E E R \_S I Z E_{i, j, t}$ & $\begin{array}{c}-0.00294^{* * *} \\
(0.00016)\end{array}$ & $\begin{array}{c}-0.00291^{* * *} \\
(0.00016)\end{array}$ & $\begin{array}{c}-0.00293^{* * *} \\
(0.00016)\end{array}$ \\
\hline$F O C A L_{-} P 2 B_{i, j, t}$ & $\begin{array}{l}-0.00003 \\
(0.00003)\end{array}$ & $\begin{array}{l}-0.00003 \\
(0.00003)\end{array}$ & $\begin{array}{l}-0.00004 \\
(0.00003)\end{array}$ \\
\hline PEER_P2 $2 B_{i, j, t}$ & $\begin{array}{l}-0.00005 \\
(0.00005)\end{array}$ & $\begin{array}{l}-0.00005 \\
(0.00005)\end{array}$ & $\begin{array}{l}-0.00004 \\
(0.00005)\end{array}$ \\
\hline TNIC_SCORE $E_{i, j, t}$ & $\begin{array}{c}0.02721^{* * *} \\
(0.00586)\end{array}$ & $\begin{array}{c}0.02675 * * * \\
(0.00587)\end{array}$ & $\begin{array}{c}0.02709 * * * \\
(0.00586)\end{array}$ \\
\hline PEER_REPORTS_FIRST $T_{i, j, t}$ & $\begin{array}{c}-0.00208^{* * *} \\
(0.00064)\end{array}$ & $\begin{array}{c}-0.00208^{* * *} \\
(0.00064)\end{array}$ & $\begin{array}{c}-0.00192 * * * \\
(0.00065)\end{array}$ \\
\hline CONSTANT & $\begin{array}{c}0.04620 * * * \\
(0.00401)\end{array}$ & $\begin{array}{c}0.04634 * * * \\
(0.00400)\end{array}$ & $\begin{array}{c}0.04619 * * * \\
(0.00406)\end{array}$ \\
\hline Observations & 6,570 & 6,570 & 6,570 \\
\hline Calendar Quarter-Year FE & Yes & Yes & Yes \\
\hline Adjusted R-squared & 0.147 & 0.147 & 0.148 \\
\hline
\end{tabular}


Table 8: Are Peer Firm Mentions by Management Informative to Peer Firm Equity Investors?

\section{An Alternative Control Sample}

Table 8 presents the results from ordinary least squares regression equation (2). The analysis in this table differs from that of Table 7 by using a different control sample: for each mentioned peer firm observation, instead of randomly picking an unmentioned peer firm from the same set of peers for the given focal firm and quarter, the analysis in this table uses the sample of unmentioned peer observations for the same focal firm and peer firm combination from different quarters. The analysis in this table also differs from that of Table 7 in that it excludes calendar quarter-year fixed effects in order to keep the desired comparisons across quarters. See the notes of Table 7 for other regression details.

Panel A: Management First Mentions Peer Firms in Either Section of the Conference Call

\begin{tabular}{|c|c|c|c|}
\hline VARIABLES & $\begin{array}{c}(1) \\
A B S_{-} P E E R_{-} C A R 2_{i, j, t}\end{array}$ & $\begin{array}{c}(2) \\
A B S_{-} P E E R_{-} C A R 2_{i, j, t}\end{array}$ & $\begin{array}{c}\text { (3) } \\
A B S_{-} P E E R_{-} C A R 2_{i, j, t}\end{array}$ \\
\hline PEER_MENTION $N_{i, j, t}$ & $\begin{array}{c}0.00055 \\
(0.00035)\end{array}$ & & \\
\hline$P E E R \_M E N T I O N \_C O U N T_{i, j, t}$ & & $\begin{array}{l}0.00022^{* *} \\
(0.00010)\end{array}$ & \\
\hline BETTER_MENTION $N_{i, j, t}$ & & & $\begin{array}{l}-0.00012 \\
(0.00045)\end{array}$ \\
\hline WORSE_MENTION $N_{i, j, t}$ & & & $\begin{array}{c}0.00129 * * \\
(0.00050)\end{array}$ \\
\hline$A B S_{-} F O C A L_{-} E A_{-} S U R_{i, j, t}$ & $\begin{array}{c}0.04978 * * * \\
(0.00918)\end{array}$ & $\begin{array}{c}0.04968^{* * *} \\
(0.00919)\end{array}$ & $\begin{array}{c}0.05072^{* * *} \\
(0.00921)\end{array}$ \\
\hline FOCAL_SIZE $E_{i, j, t}$ & $\begin{array}{c}0.00003 \\
(0.00009)\end{array}$ & $\begin{array}{c}0.00003 \\
(0.00009)\end{array}$ & $\begin{array}{c}0.00003 \\
(0.00009)\end{array}$ \\
\hline$P E E R \_S I Z E_{i, j, t}$ & $\begin{array}{c}-0.00257^{* * *} \\
(0.00010)\end{array}$ & $\begin{array}{c}-0.00257^{* * *} \\
(0.00010)\end{array}$ & $\begin{array}{c}-0.00256^{* * *} \\
(0.00010)\end{array}$ \\
\hline$F O C A L_{-} P 2 B_{i, j, t}$ & $\begin{array}{c}-0.00006^{* *} \\
(0.00003)\end{array}$ & $\begin{array}{c}-0.00006^{* *} \\
(0.00003)\end{array}$ & $\begin{array}{c}-0.00006^{* *} \\
(0.00003)\end{array}$ \\
\hline PEER_P2 $B_{i, j, t}$ & $\begin{array}{l}-0.00005 \\
(0.00003)\end{array}$ & $\begin{array}{l}-0.00005 \\
(0.00003)\end{array}$ & $\begin{array}{c}-0.00004 \\
(0.00003)\end{array}$ \\
\hline TNIC_SCORE $E_{i, j, t}$ & $\begin{array}{c}0.02618^{* * *} \\
(0.00357)\end{array}$ & $\begin{array}{c}0.02594^{* * *} \\
(0.00356)\end{array}$ & $\begin{array}{c}0.02613^{* * *} \\
(0.00356)\end{array}$ \\
\hline PEER_REPORTS_FIRST $T_{i, j, t}$ & $\begin{array}{c}-0.00272 * * * \\
(0.00036)\end{array}$ & $\begin{array}{c}-0.00271^{* * *} \\
(0.00036)\end{array}$ & $\begin{array}{c}-0.00267^{* * *} \\
(0.00037)\end{array}$ \\
\hline CONSTANT & $\begin{array}{c}0.04077^{* * *} \\
(0.00103)\end{array}$ & $\begin{array}{c}0.04079 * * * \\
(0.00103)\end{array}$ & $\begin{array}{c}0.04071^{* * *} \\
(0.00103)\end{array}$ \\
\hline Observations & 19,170 & 19,170 & 19,170 \\
\hline Adjusted R-squared & 0.0751 & 0.0753 & 0.0753 \\
\hline
\end{tabular}


Panel B: Management First Mentions Peer Firms in the Discussion Section of the Conference Call

\begin{tabular}{|c|c|c|c|}
\hline VARIABLES & $\begin{array}{c}(1) \\
A B S_{-} P E E R_{-} C A R 2_{i, j, t}\end{array}$ & $\begin{array}{c}(2) \\
A B S_{-} P E E R_{-} C A R 2_{i, j, t}\end{array}$ & $\begin{array}{c}\text { (3) } \\
A B S_{-} P E E R \_C A R 2_{i, j, t}\end{array}$ \\
\hline PEER_MENTION $N_{i, j, t}$ & $\begin{array}{l}0.00084 * \\
(0.00043)\end{array}$ & & \\
\hline PEER_MENTION_COUNT $T_{i, j, t}$ & & $\begin{array}{c}0.00027^{* *} \\
(0.00013)\end{array}$ & \\
\hline BETTER_MENTION $_{i, j, t}$ & & & $\begin{array}{c}0.00013 \\
(0.00055)\end{array}$ \\
\hline WORSE_MENTION $N_{i, j, t}$ & & & $\begin{array}{c}0.00159^{* * *} \\
(0.00061)\end{array}$ \\
\hline$A B S_{-} F O C A L_{-} E A_{-} S U R_{i, j, t}$ & $\begin{array}{c}0.04387^{* * *} \\
(0.01010)\end{array}$ & $\begin{array}{c}0.04395 * * * \\
(0.01012)\end{array}$ & $\begin{array}{c}0.04491^{* * *} \\
(0.01012)\end{array}$ \\
\hline$F O C A L \_S I Z E_{i, j, t}$ & $\begin{array}{c}0.00003 \\
(0.00011)\end{array}$ & $\begin{array}{c}0.00002 \\
(0.00011)\end{array}$ & $\begin{array}{c}0.00003 \\
(0.00011)\end{array}$ \\
\hline$P E E R \_S I Z E_{i, j, t}$ & $\begin{array}{c}-0.00265 * * * \\
(0.00012)\end{array}$ & $\begin{array}{c}-0.00264 * * * \\
(0.00012)\end{array}$ & $\begin{array}{c}-0.00264^{* * *} \\
(0.00012)\end{array}$ \\
\hline$F O C A L_{-} P 2 B_{i, j, t}$ & $\begin{array}{l}-0.00007^{*} \\
(0.00004)\end{array}$ & $\begin{array}{l}-0.00007^{*} \\
(0.00004)\end{array}$ & $\begin{array}{c}-0.00008^{* *} \\
(0.00004)\end{array}$ \\
\hline$P E E R_{-} P 2 B_{i, j, t}$ & $\begin{array}{l}-0.00006 \\
(0.00004)\end{array}$ & $\begin{array}{l}-0.00006 \\
(0.00004)\end{array}$ & $\begin{array}{l}-0.00005 \\
(0.00004)\end{array}$ \\
\hline TNIC_SCORE $E_{i, j, t}$ & $\begin{array}{c}0.02662^{* * *} \\
(0.00416)\end{array}$ & $\begin{array}{c}0.02630^{* * *} \\
(0.00416)\end{array}$ & $\begin{array}{c}0.02657^{* * *} \\
(0.00415)\end{array}$ \\
\hline PEER_REPORTS_FIRST $T_{i, j, t}$ & $\begin{array}{c}-0.00257^{* * *} \\
(0.00045)\end{array}$ & $\begin{array}{c}-0.00257^{* * *} \\
(0.00045)\end{array}$ & $\begin{array}{c}-0.00251^{* * *} \\
(0.00045)\end{array}$ \\
\hline CONSTANT & $\begin{array}{c}0.04143^{* * *} \\
(0.00121)\end{array}$ & $\begin{array}{c}0.04147^{* * *} \\
(0.00121)\end{array}$ & $\begin{array}{c}0.04136^{* * *} \\
(0.00121)\end{array}$ \\
\hline Observations & 13,248 & 13,248 & 13,248 \\
\hline Adjusted R-squared & 0.0769 & 0.0770 & 0.0771 \\
\hline
\end{tabular}

